2

\title{
ANÁLISE DA DESVINCULAÇÃO FINALÍSTICA DAS CONTRIBUIÇÕES
}

Luís Eduardo Silva de Souza

\section{INTRODUÇÃO}

Em que pese não ser difícil chegar-se a conclusão de que, no Ordenamento Jurídico Brasileiro, considerando a destinação finalística das contribuições, estas são espécie autônoma do gênero tributo - visão esta que se assemelha a de ordenamentos jurídicos estrangeiros -, existem estudiosos que questionam o caráter autônomo dessa espécie tributária.

Destarte, é necessário analisar a regra-matriz de incidência das Contribuições, sobretudo para averiguar se a afetação da arrecadação compõe algum dos critérios formadores da regra-matriz, não obstante seja plenamente inteligível que, de qualquer forma, é a destinação vinculada das Contribuições que confere constitucionalidade a esta espécie tributária e a distingue das demais.

Como se verá, no entanto, o ponto peculiar às contribuiçôes que lhes atribui autonomia, qual seja, a destinação finalística, suscita debate de extrema relevância quando se pensa, então, na desvinculação finalística do produto arrecadado pela Fazenda Pública.

Por conseguinte, é inevitável imaginar que, quando o Estado, através da manifestação do Poder Legislativo e do Poder Constituinte Derivado Reformador, pretende fazer nascer norma que permita aplicação de receita oriunda de arrecadação das Contribuições à finalidade diversa da originalmente pretendida pela Constituição, a norma inovadora estará maculada de inconstitucionalidade. 
-. Tributação, direitos fundamentais e desenvolvimento

É nesse sentido que não se pode admitir que uma lei que institua um contribuição, estabeleça destinação da arrecadaçãa à finalidade não disposta na Constituição como capaz de justificar o recolhimento do tributo. De igual modo, Lei Orçamentária de modo algum está autorizada a desvincular contribuição do fim a que se refere a Constituição e sua lei instituidora. Ainda, não pode ser concedida ao constituinte derivado a faculdade de autorizar a tredestinação do produto das contribuições.

A despeito disso, a desvinculação finalística das Contribuições vem sendo legitimada por Emendas Constitucionais que, desde 1994, por meio de norma inserida no texto do Ato das Disposições Constitucionais Transitórias, autorizam a destinação do produto arrecadado à finalidades estranhas ao seu mandamento original.

A aludida norma de desvinculação atinge principalmente as Contribuições Sociais, cuja receita deve ser destinada ao custeio da seguridade social e contribui para a famigerada crise na Previdência Social, um tanto quanto questionável, já que o montante arrecadado anualmente com as Contribuições criadas para serem destinadas a tais despesas é suficiente para custear todo o gasto e, mais ainda, realizar investimentos.

Desse modo, é cediço buscar no Poder Judiciário uma solução para toda a problemática envolvendo normas em vigor no Ordenamento. E, não apenas isso, será demonstrado que a atuação do legislativo pode auxiliar o custeio das despesas gerais da União sem que seja necessária a desvinculação das contribuições, além de evitar um Sistema Tributário obscuro, sem transparência para os contribuintes.

\section{NOÇÕES GERAIS ACERCA DAS CONTRIBUIÇÕES}

No fito de inserir o leitor no contexto do presente trabalho de modo a criar-se uma base para melhor compreensão das contribuições e porque a discussão acerca da desvinculação de seus recursos é tão importante, faz-se mister apresentar noções gerais acerca desse tributo.

\subsection{Apanhado histórico}

De início, traz-se uma síntese de como as contribuições são entendidas e normatizadas em outros países, bem como da regulação que receberam em nossas Constituições anteriores. 


\subsubsection{Contribuições no direito comparado}

Diversos países ao redor do mundo preveem as contribuições especiais em seus ordenamentos. Como será exposto a seguir, não há uma uniformidade no tratamento concernido a esta espécie tributária, mas, ao contrário, sempre são verificados elementos característicos em cada Pátria.

$\mathrm{Na}$ Itália, por exemplo, esse tributo vem sendo considerado pela doutrina predominante e pelas Cortes de Justiça como uma espécie de imposto. O ponto nevrálgico do debate está na tese sustentada por doutrinadores que defendem a autonomia das contribuiçôes: eles apontam que estas se diferem dos demais tributos por conta da afetação do produto da arrecadação ${ }^{1}$.

De modo diverso do Sistema Italiano e do Sistema Brasileiro - que será estudado aos pormenores no presente trabalho -, a Espanha, apesar de ter reconhecido a autonomia das contribuições, definiu-as como tributos existentes quando há atividade específica do Poder Público que proporcione benefício ao contribuinte ${ }^{2}$, assemelhando-se com as taxas no Ordenamento Brasileiro.

Na Alemanha, compõem o Sistema Tributário quatro espécies tributárias. São elas: contribuiçôes especiais, taxas, impostos - estes últimos com categoria especial de impostos vinculados, relacionados a prestações ou finalidades específicas da Administração - e, nas palavras de Andrei Pitten Velloso e Leandro Paulsen "exações destinadas a satisfazer necessidades financeiras especiais e não compreendidas no orçamento geral do Estado, sendo cobradas de grupos específicos de obrigados tributários"3.

Para o Ordenamento Jurídico Alemão, as contribuições especiais possuem a finalidade primordial de custear as despesas da Administração Pública que ensejem direta ou potencialmente benefício a determinado contribuinte. Trata-se de tributo que deve ser usado para custeio de ações específicas do Poder Público, exigido temporariamente de grupos específicos que estejam em situação que os coloquem na posição de responsável pelas despesas em questão ${ }^{4}$.

É interessante destacar, por fim, que Portugal é adepto da tripartição das espécies tributárias em impostos, taxas e contribuições especiais, com algumas destas

\footnotetext{
PAULSEN, Leandro; VELLOSO, Andrei Pitten. Contribuiçôes: teoria geral. Contribuições em espécie. 2. ed. Porto Alegre: Livraria do Advogado, 2013, p. 13.

Ibidem, p. 14.

PAULSEN, Leandro; VELLOSO, Andrei Pitten. Op. cit., p. 16.

Ibidem, p. 17.
} 
•• Tributação, direitos fundamentais e desenvolvimento

incluídas na categoria de impostos sempre que beneficiarem o contribuinte ou aumentar valor de seus bens por obra pública ou ampliação de serviço público5.

Nota-se que a destinação do produto da arrecadação das contribuições é corriqueiramente levado em conta para classifica-las. No Brasil, esse ponto passou a ser mais relevante com o advento da Constituição da República de 1988. Antes disso, as contribuições especiais eram tratadas de modo bem diferente pelas Cartas anteriores, conforme será exposto abaixo.

\subsubsection{Contribuições nas Constituições brasileiras}

Em nosso Ordenamento Jurídico, afirma-nos Andrei Pitten Velloso e Leandro Paulsen que as contribuições - lato sensu, não se referindo especificamente as contribuições especiais - foram claramente previstas no texto constitucional somente com a Constituição de 1934, que permitiu a cobrança de contribuição de melhoria, apresentando a mesma ideia que se tem atualmente desta espécie tributária, que é devida quando o contribuinte aufere benefício decorrente da realização de obra pública por ser proprietário de imóvel nos entornos da obra ${ }^{6}$. As Cartas de 1824 e 1891, impregnadas dos ideais e estruturas do Império e da República Velha, respectivamente, não trouxeram as contribuições em seu bojo 7 .

A Constituição de 1937, contudo, foi a pioneira no que tange à previsão de contribuições especiais, ao dispor sobre as contribuições que poderiam ser cobradas por sindicatos devidamente reconhecidos pelo Estado e também sobre a contribuição previdenciária - em benefício da maternidade, vítimas de doenças, idade avançada e morte ${ }^{8}$.

Todas estas marcaram presença também na Carta de 1946, assim como na de 1967, que somou as já existentes às contribuições para custeio dos gastos com a intervenção da União Federal no domínio econômico?.

Observa-se que em 1967 já tínhamos delineadas na base de nosso Direito contribuições especiais existentes atualmente, tanto as de cunho social como as de

\footnotetext{
Ibidem, p. 18.
}

6 SCHOUERI, Luís Eduardo. Direito tributário. 3. ed. São Paulo: Saraiva, 2013, p. 190.

7 PAULSEN, Leandro; VELLOSO, Andrei Pitten. Op. cit., p. 19.

8 BARRETO, Paulo Ayres. Contribuiçôes: regime jurídico, destinação e controle. São Paulo: Noeses, 2006, p. 90.

9 PAULSEN, Leandro; VELLOSO, Andrei Pitten. Op. cit., p. 19. 
intervenção no domínio econômico. A Constituição dos primeiros anos do Regime Militar, inclusive, tratou de maneira mais expressiva das contribuições de interesse das categorias profissionais ao determinar a delegação da arrecadação da contribuição destinadas a financiar as atividades de entidades de classe, que seria a estas entregue pelo Poder Público ${ }^{10}$.

Com o advento da Emenda Constitucional n. 1 de 1969 - não adentrando aqui na discussão acerca de sua natureza, se foi uma nova Constituição ou apenas uma Emenda que trouxe mudanças expressivas -, passaram a figurar no Texto Constitucional também as contribuições previdenciárias, completando o quadro que se manteve no Sistema Tributário trazido pela Carta Política de $1988^{11}$.

A previsão expressa das contribuições especiais nas Constituições Brasileiras desde a Carta de 1937, de modo algum significa que durante todo esse interregno elas foram vistas em absoluto como espécie tributária autônoma, como será demonstrado a seguir.

\subsection{Os tributos no Brasil}

A falta de clareza sobre a autonomia das contribuições como espécie tributária pairou sobre a doutrina e a jurisprudência até a promulgação da Constituição Federal de 1988. Inobstante, ainda hoje a questão não é totalmente pacificada. Vejamos, para compreender melhor a temática, os tributos na história brasileira e as teorias que permeiam as espécies tributárias.

\subsubsection{Os tributos em nossa história}

Nos primórdios da história brasileira, a exploração da Colônia protagonizada por Portugal incluiu intensa arrecadação tributária, que em grande parte era direcionada à Coroa. Esta encontrou na tributação da Colônia uma forma de se livrar das dificuldades e arcar com seus prejuízos, como ocorreu quando o Reinado Português se livrou da Espanha entre os séculos XVIII e XIX e a indenização paga pelos portugueses, que foi custeada através do quantum arrecadado no Brasil-Colônia ${ }^{12}$.

10 Ibidem, p. 20.

11 Ibidem, p. 20.

12 OLIVEIRA, Régis Fernandes de. Curso de direito financeiro. 5. ed. São Paulo: RT, 2013, p. 88-89. 
-. Tributação, direitos fundamentais e desenvolvimento

Os proprietários de terras, sobretudo os que se beneficiavam do cultivo de produtos naturais, eram alvo de tributação pesada, como é o caso dos produtores de pau-brasil, estavam obrigados a pagar concessóes ao Império Português, sob pena de não mais exercerem suas atividades ${ }^{13}$.

Assim também era ao tempo das Capitanias Hereditárias, em que os ditos controladores deveriam recolher certo montante à Portugal a fim de garantir autorização para explorar a terra. A mesma ideia de arcar com tributos para obter chancela da Coroa quanto à exploração dos produtos extraídos da natureza seguiu com a exploração da cana-de-açúcar, da pesca e da mineração ${ }^{14}$.

Até a Independência, a tributação continuou a ocorrer de forma desorganizada, sem observância de qualquer regramento sólido que regulasse a arrecadação da Coroa. Ao contrário, em consonância com o sistema político-jurídico da época, muito se desviava e pouco se preocupava em criar tributos que não fossem completamente arbitrários e injustos. Para se ter uma ideia, até mesmo a passagem dos rios era tributada por meio da barcagem $^{15}$.

Somente com a outorga da primeira Constituição Brasileira em 1824 os tributos ganharam organização positivada ${ }^{16}$. É certo que as diversas Constituiçõos de nossa história são marcadas pelas mudanças de contexto sócio-político que permearam diversas gerações de direitos. Nesse diapasão - e não poderia ser diferente -, a Ordem Tributária Nacional apresentou vultosa transformação de 1824 a 1988, ensejando a aplicação de diferentes teorias a respeito das espécies tributárias.

Ao tempo de nossa primeira Carta Política, inobstante estarem minimamente organizados constitucionalmente, os tributos não estavam traçados de modo mais preciso, cada um com os atributos que lhe são peculiares. Durante o período imperial, o que se via eram impostos divididos entre Receitas Nacionais e Receitas Municipais - estas últimas referentes às Administrações Provinciais - que, como já afirmado acima, eram habitualmente subvertidas pelo Governo Central ${ }^{17}$.

\footnotetext{
Ibidem, p. 89.

Ibidem, p. 89.

Ibidem, p. 90.

Ibidem, p. 92.

BALEEIRO, Aliomar. Uma introdução à ciência das finanças. 15. ed. Rio de Janeiro: Forense, 1997, p. 295.
} 
Juntamente com a Proclamação da República, estabeleceu-se a ordem federalista e, consequentemente, as competências tributárias foram melhor delineadas, embora os Municípios só tenham ganhado seu lugar na repartição de competências para tributar com a Constituição de $1937^{18}$.

A redemocratização do País que sucedeu o Estado Novo, fez nascer a Constituição de 1946 e nela os tributos eram, de acordo com a teoria tripartite, distinguidos em três espécies, quais sejam, impostos, taxas e contribuição de melhoria ${ }^{19}$.

Essa tese, estimulada pela febre de estudos do fato gerador como centro da ciência jurídico-tributária ${ }^{20}$, atravessou todo o período de Governo Militar e inspirou a edição da Lei n. 5.172/1966, nosso Código Tributário Nacional, recepcionado pela Constituição Federal de 1988 e vigente até hoje $\mathrm{e}^{21}$.

\subsubsection{As teorias sobre as espécies tributárias}

Quando falamos em espécies tributárias, estamos nos referindo sempre a um mesmo gênero, qual seja, os tributos. A diferenciação se dá, como é possível inferir do que já fora exposto no presente trabalho, por características específicas de cada tributo, que vão ensejar tratamento jurídico diferenciado dentro de um mesmo regime jurídico geral dos tributos ${ }^{22}$.

Assim sendo, é imperioso trazer um conceito de tributo. Nos dizeres de Paulo Ayres Barreto ${ }^{23}$, trata-se de "prestação pecuniária compulsória, ex lege, que não constitui sanção de ato ilícito, cobrada mediante atividade administrativa vinculada”. No mesmo sentido, preconiza Velloso e Paulsen ${ }^{24}$, ao afirmar que, se nos referirmos a "prestações pecuniárias compulsórias que não derivam de fatos ilícitos", estamos falando de tributos.

De igual modo, o Código Tributário Nacional prevê em seu artigo 3º o conceito legal de tributo como "toda prestação pecuniária compulsória, em moeda ou

18 OLIVEIRA, Régis Fernandes de. Op. cit., p. 93-94.

19 Ibidem, p. 94.

20 SCHOUERI, Luís Eduardo. Op. cit., p. 162.

21 OLIVEIRA, Régis Fernandes de. Op. cit., p. 95.

22 SCHOUERI, Luís Eduardo. Op. cit., p. 157.

23 BARRETO, Paulo Ayres. Op. cit., p. 73.

24 PAULSEN, Leandro; VELLOSO, Andrei Pitten. Op. cit., p. 28. 
-• Tributação, direitos fundamentais e desenvolvimento

cujo valor nela se possa exprimir, que não constitua sanção de ato ilícito, instituída em lei e cobrada mediante atividade administrativa plenamente vinculada" 25 .

Nesse diapasão, são inúmeras as teses que tratam da espécies tributárias existentes e de modo algum o tema será esgotado no presente trabalho - afinal, nem mesmo uma obra doutrinária seria capaz de tamanha façanha. Inobstante, frise-se que qualquer classificação dos tributos, deve ser consectário das normas e princípios constitucionais contemporâneos.

Sobre a questão, Schoueri enuncia que:

Não há uniformidade quanto ao número de espécies e seus critérios. Podem-se identificar, conforme o critério, apenas duas espécies de tributos (vinculados ou não vinculados); três (impostos, taxas e contribuiçōes); quatro (acrescentando os empréstimos compulsórios); cinco (identificando as contribuições de melhoria) ${ }^{26}$

$\mathrm{O}$ aludido autor traz, ainda, uma sexta possibilidade ao defender a existência de "seis espécies: impostos, taxas, contribuições de melhoria, empréstimos compulsórios, contribuições sociais e contribuições especiais" 27.

Entretanto, sem diminuir a importância e a inteligência das diferentes correntes doutrinárias acerca do tema, o presente trabalho se limitará a expor de modo mais minucioso as duas principais teorias que são extraídas do Código Tributário Nacional e da Constituição da República de 1988, respectivamente: a teoria tripartite e a teoria quinquipartite.

\subsubsection{A teoria tripartite}

de acordo com a teoria tripartite, predominante na América Latina ${ }^{28}$, existem, logicamente, conforme já exposto acima, três espécies tributárias em nosso Ordenamento: impostos, taxas e contribuições.

Essa tese parte da premissa de que existem (i) tributos vinculados a uma ação do Poder Público, (ii) tributos não vinculados a uma ação do Poder Público e (iii) tributos que, embora vinculados a uma atuação estatal, esta não é dirigida especi-

\footnotetext{
25 BRASIL. Lei n. 5.172, de 25 de Outubro de 1966. Dispõe sobre o Sistema Tributário Nacional e institui normas gerais de direito tributário aplicáveis à Uniāo, Estados e Municípios. Diário Oficial da Uniāo. Distrito Federal, 27 de Outubro de 1966.

26 SCHOUERI, Luís Eduardo. Op. cit., p. 157.

27 Ibidem, p. 157.

28 Ibidem, p. 158.
} 
ficamente ao contribuinte que efetuou o pagamento ao Estado. No primeiro caso, temos as taxas, no segundo os impostos e, por fim, as contribuiçôes ${ }^{29}$.

O Código Tributário Nacional, influenciado pela contexto da época de sua edição, consagrou a teoria tripartite ao dispor em seu artigo $5^{\circ}$ que "os tributos são impostos, taxas e contribuições de melhoria" ${ }^{30}$.

Como se observa na leitura do aludido texto legal, em que pese a teoria tripartite fazer referência às contribuições de modo geral, o codex tributário positivou como espécie tributária apenas as contribuições de melhoria - muito inspirada nas contribuições alemãs destinadas ao cuidado com ruas e praças -, não tratando das demais $^{31}$.

No viés de incompletude da teoria tripartite, o CTN dispôs sobre os critérios que devem ser utilizados para distinguir uma espécie tributária das demais, nos termos de seu artigo $4^{032}$. Estes critérios trazidos pelo CTN suscitam discussōes interessantes, conforme bem aponta Schoueri. O autor destaca que a irrelevância da "denominação" no inciso I, por exemplo, é excelente para ajudar delinear a distinção dos tributos, haja vista que impede os Entes de usurparem competências que não lhe foram atribuídas criando tributos que são, essencialmente, outra espécie tributária, apenas com nome diverso para se esquivar da inconstitucionalidade ${ }^{33}$.

Por outro lado, desconsiderar a "destinação" significa dizer, a título exemplificativo, que os empréstimos compulsórios são taxas ou impostos restituíveis ao contribuinte e não uma espécie tributária autônoma ${ }^{34}$.

Nesse diapasão, como se percebe, a insuficiência da teoria em comento está, sobretudo, no fato de que os traços distintivos não são muito precisos para estabe-

29 SCHOUERI, Luís Eduardo. Op. cit., p. 158.

30 BRASIL. Lei n. 5.172, de 25 de Outubro de 1966. Dispõe sobre o Sistema Tributário Nacional e institui normas gerais de direito tributário aplicáveis à União, Estados e Municípios. Diário Oficial da União. Distrito Federal, 27 de outubro de 1966.

31 SCHOUERI, Luís Eduardo. Op. cit., p. 159.

32 Art. $4^{\circ}$ A natureza jurídica específica do tributo é determinada pelo fato gerador da respectiva obrigação, sendo irrelevantes para qualificá-la: I - a denominação e demais características formais adotadas pela lei; II - a destinação legal do produto da sua arrecadação. BRASIL. Lei n. 5.172, de 25 de outubro de 1966. Dispóe sobre o Sistema Tributário Nacional e institui normas gerais de direito tributário aplicáveis à União, Estados e Municípios. Diário Oficial da Uniāo. Distrito Federal, 27 de outubro de 1966.

33 SCHOUERI, Luís Eduardo. Op. cit., p. 159.

34 Ibidem, p. 162. 
•• Tributação, direitos fundamentais e desenvolvimento

lecer o tratamento jurídico dado aos contribuintes pela Constituição da República diante das espécies tributárias trazidas intencionalmente pelo constituinte ${ }^{35}$, de modo que não dá azo à individualização das contribuições e dos empréstimos compulsórios, identificados pela vinculação finalística e pelo compromisso de restituição, respectivamente ${ }^{36}$.

\subsubsection{A Teoria Quinquipartite}

Posteriormente ao advento do Código Tributário Nacional, foi outorgada a Constituição de 1967, que seguiu com a Emenda Constitucional n. 1 de 1969. Nessa época, já discutia-se muito se a classificação proposta pelo CTN deveria ser mantida ou se era necessário tecer novos critérios ${ }^{37}$.

A divisão doutrinária consistia, basicamente, em duas correntes: uma que entendia suficiente a classificação das espécies tributárias como era até então, por estar de acordo com a Ordem Constitucional vigente. A outra corrente doutrinária, sustentava uma nova proposta calcada em aspectos diferenciadores importantes e mais apropriados, tais como a destinação do produto da arrecadaçãao e a previsão de restituição do valor recolhido pelo contribuinte aos cofres públicos ${ }^{38}$.

Interessante destacar observação feita por Paulo Ayres Barreto, simpatizante da corrente defensora da insuficiência da teoria tripartite, segundo o qual a destinação é um critério capaz de particularizar um tributo, considerando que compõe o regime jurídico próprio deste ${ }^{39}$.

A Constituição de 1988 foi promulgada ultrapassando a classificação estrita trazida pela teoria tripartite. Com a nova Ordem trazida por nossa atual Carta Política, não há conclusão mais acertada do que aquela que entende existirem cinco espécies distintas do gênero tributo, quais sejam, impostos, taxas, contribuições de melhoria, contribuições especiais e empréstimos compulsórios.

A aludida tese é facilmente verificável numa análise simples do texto constitucional, de que o artigo 145 traz os impostos as taxas e contribuições de melhoria e o artigo 148 e 149, no mesmo capítulo "Do Sistema Tributário Nacional", tratam

\section{Ibidem, p. 162.}

36 PAULSEN, Leandro. Curso de direito tributário. 4. ed. Porto Alegre: Livraria do Advogado, 2012, p. 42.

37 BARRETO, Paulo Ayres. Op. cit., p. 55.

38 Ibidem, p. 55.

39 Ibidem, p. 55. 
dos empréstimos compulsórios e das contribuições especiais, todos com competência para instituição bem delineada ${ }^{40}$.

Cumpre ressaltar que, segundo destaca Barreto, mesmo diante do que parece ser uma obviedade da Constituição, existem doutrinadores que negam a autonomia das contribuiçôes, como faz Marco Aurélio Greco, que as considera uma figura sui generis, considerando para tanto que, se o constituinte quisesse incluí-las no grupo dos tributos, as teria colocado ao lado dos impostos, taxas e contribuições de melhoria no artigo $145^{41}$.

Certo é, como visto, que não existe apenas uma única maneira de se chegar à teoria quinquipartite. A verdade é que é possível adotar premissas distintas alcançadas a partir do estudo do Ordenamento Jurídico, sobretudo do Sistema Tributário em cotejo com a Ciência das Finanças, tendo como resultado critérios que variam bastante. Nos próximos tópicos, a questão será retomada.

\subsection{Afinal, como definir contribuições?}

Atualmente, conforme interpretação sistemática da Constituição Federal nos termos já expostos acima, temos que as Contribuições são uma espécie tributária autônoma, com traços próprios que as distinguem das demais. Subsistem, contudo, inúmeras correntes doutrinárias que caminham em sentido contrário.

Curiosamente, nomes exponenciais do Direito Tributário sustentam teorias tripartidas ou bipartidas dos tributos. É o caso de Roque Antônio Carrazza e Paulo de Barros Carvalho, para os quais os tributos se dividem em impostos, taxas e contribuição de melhoria ${ }^{42}$. Alfredo Augusto Becker, por seu turno, assim como Aliomar Baleeiro, entendem que os tributos serão sempre taxas ou impostos, ainda que com suas peculiaridades ${ }^{43}$.

Desde as primeiras décadas do século passado, mesmo quando ainda eram imprecisas as qualidades das Contribuições e estas ainda não estavam delineadas como atualmente, um importante atributo que sempre foi a elas atribuído e merece ser brevemente comentado é a parafiscalidade ${ }^{44}$.

\footnotetext{
40 SCHOUERI, Luís Eduardo. Op. cit., p. 160-161.

41 BARRETO, Paulo Ayres. Op. cit., p. 93.

42 PAULSEN, Leandro; VELLOSO, Andrei Pitten. Op. cit., p. 28.

43 Ibidem, p. 29.

44 BALEEIRO, Aliomar. Op. cit., p. 288.
} 
-• Tributação, direitos fundamentais e desenvolvimento

No âmago da ciência das finanças, Aliomar Baleeiro nos mostra que a parafiscalidade representa, tradicionalmente, tributos com destinação especial a um fim, que ora se aproximam de taxas - quando são exigidas de indivíduos que se beneficiam de contraprestação do Estado - ora se assemelham a impostos - nos casos em que não há conexão entre o contribuinte e a finalidade a que se direciona a arrecadação ${ }^{45}$.

O termo, empregado originalmente na França em 1946, no famoso Inventário Schuman ${ }^{46}$, designa fenômeno no qual há "(i) delegação de capacidade tributária ativa a pessoas jurídicas de direito público ou privado; (ii) atribuição, aos delegatários, da receita arrecadada, que resta excluída do orçamento geral e se vincula às finalidades próprias da entidade beneficiária" ${ }^{\text {”7 }}$.

Inobstante haja proibição expressa da Constituição da República quanto à existência de orçamento diversos, exigindo apenas um único orçamento geral, conforme artigo $164, \$ 5^{\circ}$, a doutrina moderna ainda se utiliza do termo, sobretudo para aludir às contribuições que não são recolhidas pelos entes federativos de modo direto, mas sim por outras pessoas jurídicas através de delegação da capacidade tributária ativa, como é o caso das contribuições do Sistema $S$ e de entidades de classe ${ }^{48}$, como o Conselho Federal de Medicina.

A ideia parece muito interessante se considerarmos que as Contribuições, em que pese não serem sempre recolhidas através de delegação da capacidade tributária ativa, possuem - ou pelo menos algumas delas, como é o caso das de interesse das categorias profissionais - um aspecto parafiscal e, no entanto, assumiram papel importante no orçamento público geral nas últimas décadas, se prestando até mesmo ao custeio de gastos com fins não relacionados àquele que deveria ser o correto, em consonância com a Constituição.

Desse modo, a parafiscalidade, embora etimologicamente indique algo que está à margem da fiscalidade, na verdade, liga-se intimamente às finanças públi-

Ibidem, p. 288.

46 Trata-se de relatório coordenado pelo Ministro das Finanças francês, no ano de 1946, que listou as diversas receitas públicas existentes, conforme afirmado por: DERZI, Misabel Abreu Machado; SANTIAGO, Igor Mauler. Revista Internacional de Direito Tributário, Belo Horizonte, v. 1, n. 2, jul./dez. 2004, p. 384.

47 PAULSEN, Leandro; VELLOSO, Andrei Pitten. Op. cit., p. 21.

48 SCHOUERI, Luís Eduardo. Op. cit., p. 520. 
cas, já que impregna diversas contribuições instituídas em nosso Ordenamento Jurídico atual.

Chegar a um conceito rígido de Contribuições, mesmo partindo da premissa de que temos em nosso Ordenamento atualmente cinco espécies tributárias, é uma tarefa que permeia diversas construções teóricas acerca das classificações dos tributos.

Apenas para que se vislumbre as divergências, Fernando F. Castellani salienta que os tributos são classificados com base em três critérios extraídos da Constituição da República, quais sejam, “(i) vinculação obrigatória da materialidade a uma atividade estatal, (ii) destinação obrigatória do produto e (iii) previsão de restituição obrigatória dos valores"’49.

Nesse viés, Castellani sustenta que as contribuições são tributos não vinculados, destinados e não restituíveis, isto é, não se relaciona com qualquer atividade estatal específica em contraprestação ao valor pago pelo contribuinte, o produto de sua arrecadação deve ser necessariamente destinado à manutenção da atividade estatal que autoriza a cobrança do tributo e não há obrigatoriedade de que o produto arrecadado seja restituído ao contribuinte em momento posterior - como ocorre com os empréstimos compulsórios ${ }^{50}$.

De modo muito semelhante, porém um pouco mais complexo, Paulo Ayres Barreto propõe uma classificação sucessiva, analisando-se a classificação dos tributos necessariamente em fases, sempre partindo para a fase seguinte após esgotar-se a anterior, sendo a subsequente subordinada a anterior ${ }^{51}$.

Por essa ideia, inicialmente estuda-se se o tributo é vinculado ou não, sendo vinculado quando tem hipótese de incidência que se refere a uma ação estatal específica e não vinculado sempre que não se referir a atuação específica do Poder Público. Concluindo-se pela vinculação ou não vinculação do tributo, conforme enuncia o autor em comento, passa-se a análise do segundo atributo, qual seja, a destinaçãa ${ }^{52}$.

Nesse ponto, reflete-se se o produto da arrecadação obtida com o tributo está atado a um fim específico determinado por sua lei instituidora. No primeiro caso

49 CASTELLANI, Fernando F. Contribuiçôes especiais e sua destinação. São Paulo: Noeses, 2009, p. 43.

50 CASTELLANI, Fernando F. Op. cit., p. 48.

51 BARRETO, Paulo Ayres. Op. cit., p. 73-74.

52 Ibidem, p. 75. 
-. Tributação, direitos fundamentais e desenvolvimento

tem-se um tributo destinado e no segundo um tributo não destinado. Seguindo-se, na terceira etapa da classificação proposta por Barreto, cumpre verificar se o tributo é restituível ou não. Ou seja, essa fase cuida de analisar se o tributo deve ser devolvido ao contribuinte em momento posterior ${ }^{53}$.

Depois de todo esse processo classificatório, infere-se que o doutrinador em questão classifica as contribuições como tributo não vinculado, destinado e não restituível. Isso quer dizer que, para Barreto - chegando, finalmente, a um conceito expresso - contribuições consistem em tributos que não se relacionam a uma atuação estatal específica, mas sim a um fato estranho a isso. Além disso, são tributos cujo produto da arrecadação deve ser aplicado a uma finalidade específica prevista na Constituição e não são passíveis de restituição ao contribuinte em momento algum ${ }^{54}$.

Comungam dessa mesma conceituação - que também é a qual se filia o presente trabalho - Velloso e Paulsen. Salientam estes autores que as contribuições tem como hipótese de incidência fatos ou atos relacionados ao contribuinte e a vinculação à atividade estatal está, na verdade, na afetação da arrecadação, que obriga a aplicação dos recursos às finalidades estabelecidas quando instituídas ${ }^{55}$.

Diante disso, tem-se que as contribuições devem sempre estar atreladas a finalidade específica e esta deve estar em consonância com o que dispõe a Constituição Federal. Ou seja, o legislador, para instituir uma contribuição social, por exemplo, deve estabelecer a finalidade específica da contribuição que pretende criar nos limites do campo de custeio da seguridade social ${ }^{56}$.

Dessa forma, não é permitido instituir uma contribuição social estabelecendo finalidade que se distancie do custeio da seguridade social, afinal, a vinculação da destinação dos recursos angariados é requisito de validade, de constitucionalidade das contribuições. Não é aceitável a instituição de contribuições em desacordo com a norma constitucional de competência ${ }^{57}$.

Interessante destacar que o conceito trazido acima, surpreendentemente, não significa que todos os autores defendem que qualquer desvio na destinação é in-

\footnotetext{
Ibidem, p. 73-77.

54 Ibidem, p. 69-71.

55 PAULSEN, Leandro; VELLOSO, Andrei Pitten. Op. cit., p. 45.

56 Ibidem, p. 41.

57 Ibidem, p. 41.
} 
constitucional. Ao contrário, sustentam que a destinação diversa, pelo menos em alguns casos, não abalam a constitucionalidade das contribuições ${ }^{58}$. Este tema, contudo, será melhor discutido mais a frente.

Superada a conceituação, são necessárias outras reflexões para o desenvolvimento do presente trabalho na análise da constitucionalidade da tredestinação das contribuições. É o caso da análise da regra-matriz de incidência das contribuições, abordada no próximo capítulo.

\section{REGRA-MATRIZ DE INCIDÊNCIA E AUTONOMIA DAS CONTRIBUIÇÕES}

Conforme vimos até aqui, a vinculação do produto da arrecadação das contribuições especiais faz parte do próprio conceito dessa espécie tributária. Esta é a conclusão à qual nos leva o atual Ordenamento Jurídico Brasileiro, sobretudo por conta de nossa Carta Política em vigor. No entanto, a relação jurídico-tributária vai além de construções conceituais doutrinárias e se expressa por meio de obrigações assumidas entre um sujeito ativo - geralmente, o contribuinte - e um sujeito passivo - via de regra, o Estado ${ }^{59}$.

As aludidas obrigações que exprimem a relação jurídico-tributária, como é sabido, podem ser principais ou acessórias ${ }^{60}$, sendo estas decorrentes da lei e aquelas corolários do fato-gerador do tributo - estas últimas, sobretudo, provocam os efeitos jurídicos próprios de cada tributo e criam deveres e direitos a ambos os polos da relação ${ }^{61}$. Temos a ocorrência de um fato, previsto em lei - diga-se, stricto sensu que por sua mera verificação fática, cria uma relação jurídico-tributária expressa na obrigação $^{62}$.

A situação prevista como fato-gerador do tributo, e seus contornos consubstanciam a regra-matriz de incidência tributária ${ }^{63}$, que será objeto do presente capítulo, sobretudo para, em seguida, alcançar a regra-matriz de incidência das

\footnotetext{
58 Ibidem, p. 66.

59 SCHOUERI, Luís Eduardo. Op. cit., p. 459.

${ }^{60}$ MACHADO, Hugo Brito de. Curso de direito tributário. 24. ed. São Paulo: Malheiros, 2005, p. 122.

61 SCHOUERI, Luís Eduardo. Op. cit., p. 460.

${ }^{62}$ MACHADO, Hugo Brito de. Op. cit., p. 122.

63 SCHOUERI, Luís Eduardo. Op. cit., p. 469.
} 
•• Tributação, direitos fundamentais e desenvolvimento

contribuições e verificar, se a vinculação do produto da arrecadação ocupa posição dentro dela.

\subsection{Regra-matriz de incidência tributária}

Em linha de princípio, deve-se registrar a lição que nos deixa Schoueri, segundo o qual para tratar da regra-matriz de incidência tributária é preciso ter em mente o seguinte: "se há uma relação jurídica que vincula Estado e particular, esta surge sob o império de uma norma jurídica que a prevê como consequência da concretização de uma hipótese" ${ }^{24}$. Desse modo, nota-se que a regra-matriz de incidência prevê uma hipótese, uma situação, chamada de fato gerador, que, se praticada pelo contribuinte, dá origem à relação jurídico-tributária estabelecida entre o sujeito ativo - o contribuinte - e o sujeito passivo, normalmente o Estado ${ }^{65}$.

A regra-matriz de incidência de um tributo representa uma norma de comportamento que descreve a obrigação jurídico-tributária e os direitos e deveres que dela são corolários, além de apresentar o núcleo do respectivo tributo ${ }^{66}$.

A composição da regra-matriz se dá por um antecedente conjugado com um consequente. São momentos diversos, mas interligados que enunciam fatores da relação jurídico-tributária ${ }^{67}$ e se complementam através da conjugação entre os critérios material, temporal e espacial no antecedente e pessoal e quantitativo no consequente ${ }^{68}$.

O consequente representa, como o próprio termo já indica, uma consequência do antecedente, isto é, do fato gerador do tributo decorre a incidência do tributo, ou seja, a tributação, como consequência lógica ${ }^{69}$. Tanto o antecedente quanto o consequente serão melhor analisados a seguir.

\subsubsection{O antecedente - fato-gerador}

O fato gerador é o núcleo do antecedente da regra-matriz de incidência tributária consiste no fato gerador da obrigação tributária, isto é, a situação - que pode

\footnotetext{
64 Ibidem, p. 470.

65 Ibidem, p. 470.

${ }_{66}$ MOURA, Carolina Maria Melo de; GON, Diego Souza. Desvio de finalidade da contribuição de intervenção no domínio econômico incidente sobre combustíveis. Revista do Direito Público, v. 2, n. 1, p. 63-74, 2007, p. 64.

67 SCHOUERI, Luís Eduardo. Op. cit., p. 470.

68 MOURA, Carolina Maria Melo de; GON, Diego Souza. Op. cit., p. 64.

69 SCHOUERI, Luís Eduardo. Op. cit., p. 470.
} 
ser um fato, conjunto de fatos, situação de fato ou situação jurídica ${ }^{70}$ - trazida pela lei como ensejadora da tributação ${ }^{71}$. Deve-se atentar, contudo, para o fato de que a expressão "fato gerador" no Direito Tributário Brasileiro é vista sob duas acepções, conforme afirma Schoueri: sob uma ótica temos o fato gerador concreto - fato que se verifica no mundo real - e o sob outra temos o fato gerador abstrato - que consubstancia a hipótese de incidência prevista na lei ${ }^{72}$.

Nosso Código Tributário Nacional dedicou o Título II, do Capítulo II ao fato gerador dos tributos, inclusive dispondo sobre o momento em que se considerado ocorrido o fato gerador, conforme se observa nos artigos transcritos abaixo, que são alguns dos dispostos no referido capítulo:

Art. 114. Fato gerador da obrigação principal é a situação definida em lei como necessária e suficiente à sua ocorrência.

(...)

Art. 116. Salvo disposição de lei em contrário, considera-se ocorrido o fato gerador e existentes os seus efeitos:

I - tratando-se de situação de fato, desde o momento em que o se verifiquem as circunstâncias materiais necessárias a que produza os efeitos que normalmente lhe são próprios;

II - tratando-se de situação jurídica, desde o momento em que esteja definitivamente constituída, nos termos de direito aplicável.

Parágrafo único. A autoridade administrativa poderá desconsiderar atos ou negócios jurídicos praticados com a finalidade de dissimular a ocorrência do fato gerador do tributo ou a natureza dos elementos constitutivos da obrigação tributária, observados os procedimentos a serem estabelecidos em lei ordinária ${ }^{73}$.

$\mathrm{Na}$ leitura do artigo 116, notamos que o mesmo trata dos momentos em que considera-se ocorrido o fato gerador. No primeiro inciso, define o momento tendo por conta uma situação de fato e, inciso II, considera uma situação jurídica. A diferença está, de acordo com Schoueri, no fato de que a situação jurídica, mais do que um fato jurídico pura e simplesmente, é uma situação à qual o Ordenamento

\footnotetext{
MACHADO, Hugo Brito de. Op. cit., p. 122.

SCHOUERI, Luís Eduardo. Op. cit., p. 473.

Ibidem, p. 474.

73 BRASIL. Lei n. 5.172, de 25 de Outubro de 1966. Dispõe sobre o Sistema Tributário Nacional e institui normas gerais de direito tributário aplicáveis à União, Estados e Municípios. Diário Oficial da União. Distrito Federal, 27 de Outubro de 1966.
} 
-. Tributação, direitos fundamentais e desenvolvimento

Jurídico já atribuiu juridicidade como, por exemplo, um tributo que incide sobre um contrato celebrado entre sujeitos ${ }^{74}$. Neste caso, o direito civil atribui determinados efeitos jurídicos ao contrato, mas também é relevante para o direito tributário por ensejar a tributação $0^{75}$.

Ademais, Schoueri destaca e faz interessante observação quanto ao artigo 116, I. O autor afirma que daí se depreende a possibilidade de ser o fato gerador não um fato isolado, mas sim um conjunto de fatos e, assim sendo, cada fato é imprescindível para que ocorra o fato gerador, ou seja, impede a formação perfeita da relação jurídico-tributária ${ }^{76}$.

O fato gerador - concreto, quando ocorrido, materializando o abstrato - é, essencialmente, um ato jurídico que representa uma expressão de vontade do contribuinte, porém, graças à disposição legal - norma jurídica instituidora de tributo - dá origem à relação jurídico-tributária automaticamente, sem que seja necessária, para a produção de efeitos jurídicos, a manifestação de vontade das partes - contribuinte e Estado. Em outras palavras, o fato gerador é fato jurídico stricto sensu que adquire essa natureza por força legal ${ }^{17}$.

No que tange ao exposto no parágrafo anterior, contudo, é preciso ter em mente que a vontade do contribuinte é imprescindível para o ato que se transforma em fato jurídico stricto sensu, inobstante não tenha relevância para a obrigação de pagar o tributo própria e isoladamente, porque ainda que não queira pagar o tributo, o contribuinte está obrigado a recolher o valor aos cofres públicos ${ }^{78}-$ abstraindo-se, aqui, as hipóteses de isenção ou imunidade.

Em entendimento que parece somar algumas das exposições conceituais feitas até agora no presente trabalho, Gabriel Demetrio Domingues aponta que a hipótese de incidência das contribuiçóes é formada levando-se em conta uma atuação determinada do Poder Público em relação a um grupo social, ação esta indivisível, razão pela qual não se aufere o benefício de cada membro do respectivo grupo, mas inclui uma situação que informa a capacidade contributiva dos contribuintes para,

\footnotetext{
SCHOUERI, Luís Eduardo. Op. cit., p. 489.

MACHADO, Hugo Brito de. Op. cit., p. 127.

76 SCHOUERI, Luís Eduardo. Op. cit., p. 487-488.

77 Ibidem, p. 483

78 MACHADO, Hugo Brito de. Op. cit., p. 127.
} 
então, repartir entre eles o custo da atividade ${ }^{79}$ - essa questão da capacidade contributiva e da solidariedade será vista mais a frente.

Superados os esclarecimentos acima, cumpre abordar os elementos - também chamados critérios ou aspectos - que compõem o fato-gerador dos tributos e nos permitem identificar a hipótese ensejadora da relação jurídico-tributária $^{80}$, temática imprescindível para analisar se a afetação do produto da arrecadação das contribuições compóem a regra-matriz e, caso positivo, que posição ocupa.

\subsubsection{Os critérios material, espacial e temporal}

$\mathrm{O}$ critério material representa, em síntese, a situação descrita pela lei que gera a obrigação tributária ${ }^{81}$. De modo mais objetivo, pode-se dizer, como leciona Paulo de Barros Carvalho, que o critério material é sempre consubstanciado por um verbo - e seu respectivo complemento - que é o núcleo do antecedente da regra-matriz e pode indicar um "fazer", um "dar" ou um "ser" 82 . Ou, ainda, pelas célebres lições de Schoueri, o critério material pode estar expresso em um acontecimento, um ato ou negócio jurídico, por um estado de uma pessoa ou até mesmo pela titularidade de direitos ${ }^{83}$.

Do aspecto espacial do antecedente da regra-matriz, extrai-se duas acepçóes: a primeira, o âmbito territorial em que a lei instituidora do tributo é aplicada, bem como o espaço em que pode ocorrer o fato-gerador. Trata-se de critério que pode estar explícito na norma ou não, mas, neste caso, estará implícito no dispositivo legal e será perceptível ao intérprete ${ }^{84}$.

Conforme a segunda acepção, o critério espacial pode indicar precisamente o âmbito de aplicação da norma, caso em que o fato gerador só ocorrerá nesse espaço delimitado. Se a norma silenciar sobre este aspecto, o campo em

79 DOMINGUES, Gabriel Demetrio. Uma contribuição à teoria das contribuiçôes. 2013. 96f. Dissertação (Mestrado em Direito) - Faculdade de Direito, Universidade do Estado do Rio de Janeiro, Rio de Janeiro, 2013, p. 64.

80 CARVAlHO, Paulo de Barros. Curso de direito tributário. 18. ed. São Paulo: Saraiva, 2007, p. 266.

81 SCHOUERI, Luís Eduardo. Op. cit., p. 484-485.

82 Cf. CARVALHO, Paulo de Barros. Op. cit., p. 268-269.

83 Cf. SCHOUERI, Luís Eduardo. Op. cit., p. 494-495.

84 CARVALHO, Paulo de Barros. Op. cit., p. 270- 272. 
•• Tributação, direitos fundamentais e desenvolvimento

que pode ocorrer a tributação será imitado pelos limites de aplicação da própria norma ${ }^{85}$.

Já o critério temporal se refere ao momento, definido pela lei, em que considera-se ocorrido o fato-gerador da obrigação-jurídico tributária, nascendo, portanto, o vínculo obrigacional entre as partes - Estado e contribuinte ${ }^{86}$. Nessa senda, destaca Schoueri que os fatos-geradores podem ser instantâneos ou periódicos, sendo que, no primeiro caso, ocorrerá dentro de um período de tempo certo por sua própria natureza e, no segundo caso, será necessário que a lei estabeleça precisamente quando considerar-se-á ocorrido o fato-gerador ${ }^{87}$.

Essas são as linhas gerais dos aspectos componentes do antecedente da regra-matriz de incidência tributária. Prima facie, é de se registrar que não parece ser possível alocar a afetação da arrecadação das contribuiçóes em algum dos critérios já vistos, afinal, não representa a situação ensejadora da tributação, tampouco se refere ao território no qual pode ocorrer o tributo ou ao momento em que se considera ocorrido o fato gerador.

Infere-se, então, que, caso a questão em comento de fato faça parte da regra-matriz de incidências contribuições, estará inserida no consequente. Por conseguinte, cumpre, agora, analisá-lo.

\subsubsection{O consequente - completude da obrigação tributária}

Como visto acima, o antecedente da regra-matriz indica o fato-gerador do tributo, com a situação que o origina, o campo territorial em que pode ocorrer e o momento em que o considera ocorrido. Forma-se, então, a relação obrigacional decorrente de lei e por ela regulada, isto é, o consequente, como o próprio termo já propõe, é composto por aspectos que somente são alcançados com o antecedente formado $^{88}$.

Ato contínuo à tributação e definição das partes da relação jurídico-tributária - consequentemente, forma-se a obrigação tributária, chega-se ao sujeito ativo, sujeito passivo - formadores do critério pessoal -, base de cálculo e à alíquota do tri-

\footnotetext{
SCHOUERI, Luís Eduardo. Op. cit., p. 498.

6 CARVALHO, Paulo de Barros. Op. cit., p. 274- 277.

87 SCHOUERI, Luís Eduardo. Op. cit., p. 496.

88 Ibidem, p. 500.
} 
buto - formadores do critério quantitativo ${ }^{89}$. Nos dizeres de Carvalho, o antecedente atua como "descritor" e o consequente como "prescritor", já que um delineia o reconhecimento do fato-gerador e o outro traça o vínculo jurídico formado ${ }^{90}$.

\subsubsection{O critério pessoal}

Temos aqui parte importante da regra-matriz de incidência, representada pelos sujeitos ativo e passivo da obrigação tributária.

O sujeito ativo é o credor da obrigação da tributária, é quem tem o direito de exigir o tributo do contribuinte e pode ser tanto uma pessoa jurídica de direito público quanto de direito privado ${ }^{91}$. As de direito público, via de regra, são os entes da Federação que detém a competência constitucional para instituir o tributo - é o que afirma a doutrina ${ }^{92}$ e o Código Tributário Nacional, em seu artigo $119^{93}$. Será, no entanto, de direito privado, quando houver delegação da capacidade tributária ativa $^{94}$, como ocorre, por exemplo, com os sindicatos que recolhem contribuiçōes de interesse das categorias profissionais ou econômicas ${ }^{95}$.

No outro lado da relação obrigacional, está o sujeito passivo que é por excelência o contribuinte ${ }^{96}$. Os requisitos legais para ser sujeito passivo da obrigação tributária estão dispostos no artigo 126 do Código Tributário Nacional ${ }^{97}$ e são amplamente aceitos pela doutrina ${ }^{98}$.

Poderá o sujeito passivo ser, contudo, terceira pessoa, denominada responsável tributário 99 - vide artigo 121 do Código Tributário Nacional. O responsável tribu-

89 Ibidem, p. 499-503.

90 CARVAlHO, Paulo de Barros. Op. cit., p. 295.

91 Ibidem, p. 311.

92 SCHOUERI, Luís Eduardo. Op. cit., p. 519.

93 CARVAlHO, Paulo de Barros. Op. cit., p. 312.

94 MOURA, Carolina Maria Melo de; GON, Diego Souza. Op. cit., p. 66.

95 SCHOUERI, Luís Eduardo. Op. cit., p. 520.

96 Ibidem, p. 521.

${ }_{97}$ Art. 126. A capacidade tributária passiva independe: I - da capacidade civil das pessoas naturais; II - de achar-se a pessoa natural sujeita a medidas que importem privação ou limitação do exercício de atividades civis, comerciais ou profissionais, ou da administração direta de seus bens ou negócios; III - de estar a pessoa jurídica regularmente constituída, bastando que configure uma unidade econômica ou profissional.

98 CARVALHO, Paulo de Barros. Op. cit., p. 319-320.

99 MOURA, Carolina Maria Melo de; GON, Diego Souza. Op. cit., p. 67. 
-. Tributação, direitos fundamentais e desenvolvimento

tário não incidiu na hipótese prevista no antecedente, mas é obrigado a efetuar o pagamento do tributo ${ }^{100}$. Pode, ainda, haver solidariedade entre mais de um responsável ou contribuinte ${ }^{101}$, nos termos do artigo 124 do Código Tributário Nacional, que traz as pessoas que tenham interesse comum na situação do fato gerador e as que são solidariamente responsáveis por força de lei.

A identificação do sujeito ativo se dá a partir da hipótese de incidência prevista no antecedent $\mathrm{e}^{102}$ - o que corrobora, inclusive, a ligação entre antecedente e consequente da regra-matriz.

\subsubsection{O Critério Quantitativo}

Nesse critério, conforme dito anteriormente, identificamos a base de cálculo e alíquota do tributo, que dirão o montante a ser pago pelo contribuinte ao Estado-credor.

Sinteticamente, pode-se dizer, conforme preceitua Schoueri, que a base de cálculo consiste na quantificação do fato gerador do tributo, embora nem sempre seja assim, considerando que a base de cálculo pode ser estimada ${ }^{103}$, como ocorre no ICMS recolhido por estimativa fiscal, em que não se analisa a ocorrência do fato gerador para tributação, já que há uma presunção ocorrência do fato gerador, como acontece com o IPVA em alguns Estados ${ }^{104}$.

A alíquota, por sua vez, em apertada síntese, se conjuga com a base de cálculo do tributo de forma que uma não tem fundamento de existência sem a outra. Nas palavras de Carvalho, a alíquota "dá a compostura numérica da dívida, produzindo o valor que pode ser exigido pelo sujeito ativo, em cumprimento da obrigação que nascera pelo acontecimento do fato típico", e o autor continua, dizendo que da alíquota se extrai "um componente aritmético para a determinação da quantia que será objeto da prestação tributária” 105 .

Tanto o critério quantitativo quanto critério pessoal, bem como os critérios do antecedente da regra-matriz, foram tratados de modo superficial no presente traba-

BARRETO, Paulo Ayres. Op. cit., p. 162.

101 SCHOUERI, Luís Eduardo. Op. cit., p. 525.

102 CARVAlHO, Paulo de Barros. Op. cit., p. 315.

103 SCHOUERI, Luís Eduardo. Op. cit., p. 503-504.

104 Ibidem, p. 506.

105 CARVAlHO, Paulo de Barros. Op. cit., p. 352. 
lho, uma vez que aprofundar sobre o tema fugiria à temática proposta. $\mathrm{O}$ objetivo de registrar considerações gerais a respeito de antecedente e consequente é trazer uma noção do que consiste cada um para facilitar a exposição da regra-matriz de incidência das contribuições.

Cumpre ressaltar que, à primeira vista, não parece ser possível encaixar a destinação vinculada do produto da arrecadação das contribuições no consequente da regra-matriz. Isto porque o aspecto quantitativo, ao trazer a base de cálculo e a alíquota se distancia da aplicação dada ao produto arrecadado. Do mesmo modo, o critério pessoal, com sujeito passivo e sujeito ativo da relação jurídico-tributária não trazem a aplicação do dinheiro que ingressa aos cofres públicos para a regra-matriz. De qualquer forma, passamos à regra-matriz das contribuições.

\subsection{Regra-matriz de incidência das contribuiçõos}

De início, é importante registrar que as contribuições, como espécie tributária que são, possuem regra-matriz de incidência com a exata estrutura apresentada acima, assim como os demais tributos ${ }^{106}$. Vejamos.

\subsubsection{O antecedente}

Temos no antecedente - e não poderia ser diferente - o critério material com a descrição da hipótese que enseja a ocorrência do fato gerador quando ocorrida no plano fático, o critério espacial com o limite espacial em que pode ocorrer o fato gerador e o critério temporal, que representa o momento a partir do qual pode considerar-se ocorrido o fato gerador ${ }^{107}$.

$\mathrm{O}$ antecedente das contribuições não tem atributos próprios que permitam uma identificação de pronto da espécie tributária a partir de uma análise estrita dessa parte da regra-matriz ${ }^{108}$, eis que poderá se referir tanto a fato gerador de taxa como de imposto ${ }^{109}$.

Para melhor ilustrar a questão, temos, no primeiro caso, o clássico exemplo da Contribuição Social sobre o Lucro Líquido (CSLL), que em nada se difere da re-

\footnotetext{
106 BARRETO, Paulo Ayres. Op. cit., p. 159.

107 Ibidem, p. 159.

108 Ibidem, p. 159.

109 RODRIGUES, Sirley Aparecida Lopes et al. contribuição previdenciária à luz da regra matriz de incidência tributária. 2015, p. 36.
} 
gra-matriz do Imposto de Renda de Pessoa Jurídica (IRPJ) ${ }^{110}$. A diferença entre os dois tributos está no fato de que a contribuição social é constitucionalmente direcionada ao custeio da seguridade social, nos termos do artigo, 195 da CRFB, ao passo que o IRPJ é de livre destinação, como qualquer imposto, consoante artigo 167, IV da CRFB.

Este exemplo é muito elucidativo e, ao lê-lo, é inevitável não suscitar o seguinte questionamento: se o que difere a CSLL e o IRPJ é a afetação do produto da arrecadação da CSLL, se o montante arrecadado com esta não for destinado à seguridade social, é possível afirmar que temos, na verdade, um segundo IRPJ sendo cobrado do contribuinte? Veremos melhor essa questão adiante.

Cumpre ressaltar que o legislador ao estabelecer o antecedente deve-se atentar que as contribuições se submetem ao princípio da irretroatividade da lei tributária, isto é, não pode ser aplicada a fatos ocorridos antes de sua entrada em vigor, ainda que tenha o objetivo de apenas majorar contribuição já existente ${ }^{111}$.

\subsubsection{O consequente}

Temos, também, o consequente, com os mesmos critérios apresentados no tópico anterior, quais sejam, o pessoal - com identificação do sujeito passivo e do sujeito ativo da obrigação jurídico-tributária, ligando-se de modo especial com o critério material do antecedente, já que figurará no polo passivo da obrigação, via de regra, quem incidir na hipótese de incidência ${ }^{112}$ - e o critério quantitativo composto por alíquota e base de cálculo ${ }^{113}$.

No entanto, há, conforme salienta Gabriel Demetrio Domingues, corrente minoritária a qual se filia Luciano Dias Bicalho Camargo, que defende a tese de que a regra-matriz das contribuições, além de todos os critérios presentes na regra-matriz de incidência tributária dos demais tributos, tem em seu consequente o critério finalístico ${ }^{114}$. Isto é, a finalidade justificadora da contribuição e para a

\footnotetext{
BARRETO, Paulo Ayres. Op. cit., p. 160.

BARRETO, Paulo Ayres. Op. cit., p. 130.

112 CUNHA, Carlos Renato. Análise do arquétipo da regra-matriz de incidência tributária da contribuição para o custeio da iluminação pública. Revista de Direito Público da Procuradoria-Geral do Município de Londrina, v. 1, n. 1, p. 33-56, 2012, p. 49.

113 BARRETO, Paulo Ayres. Op. cit., p. 160, 164.

114 DOMINGUES, Gabriel Demetrio. Op. cit., p. 70.
} 
qual o produto de sua arrecadação será destinado faz parte do consequente da regra-matriz.

Dentre as principais críticas dessa corrente, Domingues destaca que ela reúne uma regra-matriz tributária e outra financeira, já que acabaria inserindo na regra-matriz questôes orçamentárias e, além disso, sustenta que a obrigatoriedade de destinação do produto arrecadado surge apenas com o pagamento e não decorre da mera instituição do tributo o que, portanto, torna o critério finalístico incongruente ${ }^{115}$.

Seguindo-se adiante, quanto ao critério pessoal, Barreto faz observações que merecem destaque. A primeira delas é a alusão à parafiscalidade, que acompanha diversas contribuições ${ }^{116}$, como é o caso das Contribuiçõoes do Sistema S. Isso implica delegação da capacidade tributária ativa e, por conseguinte, o ente responsável pela instituição do tributo não figura no polo ativo da obrigação, mas a entidade para a qual foi feita a delegação ${ }^{117}$. Demais disso, ao sujeito ativo da obrigação tributária das contribuições se aplica o exposto sobre o contribuinte e o responsável ou substituto tributário ${ }^{118}$.

O legislador, na construção da regra-matriz de incidência das contribuições, ao tratar do critério pessoal, deve definir o contribuinte levando em conta que a referibilidade permeia essa espécie tributária e, assim sendo, deve-se cotejar o custo da atividade a qual se destina a arrecadação com o grupo que se beneficia disso ${ }^{119}$.

A orientação do parágrafo anterior se aplica mesmo quando a contribuição tenha antecedente típico de imposto, defende Barreto, dada a marcante função da referibilidade, devendo esta ser conjugada com o princípio da capacidade contributiva, implacavelmente aplicável aos impostos ${ }^{120}$.

Nota-se assim, que, sob este ponto de vista, dar ao produto arrecadado com as contribuições destinação diferente da que deveria ser dada por força da Constituição Federal e da lei instituidora - exceto nos casos das contribuições para custeio da seguridade social, às quais se aplica o princípio da solidariedade ${ }^{121}$-, afeta a

\footnotetext{
115 Ibidem, p. 71 apud CAMARGOS, 2006.

116 BARRETO, Paulo Ayres. Op. cit., p. 160.

117 CUNHA, Carlos Renato. Op. cit., p. 53.

118 BARRETO, Paulo Ayres. Op. cit., p. 161.

119 Ibidem, p. 144, 163-164.

120 Ibidem, p. 164.

121 RODRIGUES, Sirley Aparecida Lopes et al. Op. cit., p. 22.
} 
•• Tributação, direitos fundamentais e desenvolvimento

própria referibilidade, afinal, não parece ser possível dividir o ônus apenas entre um grupo sendo que, na verdade, o montante percebido pelo Estado foi gasto em outra atividade, não raramente em prol de toda a sociedade e não de um grupo específico.

Discussão interessante diz respeito a aplicação ou não do princípio da capacidade contributiva às contribuiçôes. De acordo com esse princípio, o tributo deve ser instituído tendo por conta o poder financeiro, a riqueza do contribuinte que revelem suas condiçōes para arcar com o tributo ${ }^{122}$.

Parcela da doutrina, sendo esta a corrente a qual se filia Barreto, entende que as contribuições podem se submeter ao princípio da capacidade contributiva, mas nem sempre isso ocorrerá, tendo em vista que predomina o objetivo de ratear o custeio da atuação do Poder Público que representa a finalidade das contribuições entre todos os que estão no grupo que dela aproveita. Para fixar se é a capacidade contributiva que imperará, defende o autor em comento que diversos fatores devem ser levados em conta, tais como "a espécie de contribuição instituída, a específica situação de cada contribuinte dentro do grupo, a correlação entre a atividade estatal desenvolvida, de uma perspectiva genérica" ou de cada membro isoladamente ${ }^{123}$.

Inobstante, sustenta o aludido autor que traço o característico das contribuições é que a finalidade por ela observada sempre se refere a um grupo econômico ou social ${ }^{124}$.

Há, contudo, juristas que entendem que a capacidade contributiva está afastada das contribuições. É este o posicionamento de Velloso, segundo o qual a responsabilidade dos beneficiados de serem os obrigados a suportar o pagamento do tributo, ou seja, a referibilidade, poderá ser entendida de duas formas diferentes: por um lado, como (i) benefício auferido pelos contribuintes e por outro (ii) como pertinência que significa relação entre a finalidade perseguida e os contribuintes, sendo esta visão a mais coerente às contribuições brasileiras ${ }^{125}$.

A segunda acepção da referibilidade supramencionada, toca até mesmo no princípio da igualdade, tão valioso ao Sistema Tributário Nacional, que tem dispo-

122 PAULSEN, Leandro. Curso de direito tributário. 4. ed. Porto Alegre: Livraria do Advogado, 2012, p. 44.

123 BARRETO, Paulo Ayres. Op. cit., p. 143.

124 Ibidem, p. 124.

125 PAULSEN, Leandro; VELLOSO, Andrei Pitten. Op. cit., p. 56-57. 
sitivo próprio para tratar do assunto na Constituição Federal, qual seja, o artigo 150, II. De certa forma, o aludido princípio é diminuído quando tratamos das Contribuiçõoes de Interesse das Categorias Profissionais e de Intervenção no Domínio Econômico. Isto porque, apesar de continuar sendo aplicada a igualdade trazida pelo artigo $5^{\circ}$, I da CRFB/88, há certa discriminação para definir o contribuinte do tributo, já que justamente sua posição dentro de determinada categoria profissional ou no campo econômico é que serão determinantes ${ }^{126}$.

Contudo, a referibilidade não vem sendo vista pela jurisprudência como componente sem o qual as contribuiçôes estariam em absoluto eivadas de inconstitucionalidade ou invalidade. O Supremo Tribunal Federal se posiciona no sentido de que existem referibilidades indiretas e diretas, sendo esta última irrelevante às contribuições, conforme se observa no julgado abaixo, que fixou a possibilidade de cobrar a contribuição ao SEBRAE, um tipo de Contribuição de Intervenção no Domínio Econômico (CIDE), até mesmo das empresas de médio e grande porte, que não se beneficiam da atuação de intervenção no domínio econômico promovida pela SEBRAE:

Recurso Extraordinário. 2. Tributário. 3. Contribuição para o SEBRAE. Desnecessidade de Lei Complementar. 4. Contribuição para o SEBRAE. Tributo destinado a viabilizar a promoção do desenvolvimento das micro e pequenas empresas. Natureza jurídica: contribuição de intervenção no domínio econômico. 5. Desnecessidade de instituição por lei complementar. Inexistência de vício formal na instituição da contribuição para o SEBRAE mediante lei ordinária. 6. Intervenção no domínio econômico. É válida a cobrança do tributo independentemente de contraprestação direta em favor do contribuinte. 7. Recurso extraordinário não provido. 8. Acórdão recorrido mantido quanto aos honorários fixados. ${ }^{127}$

$\mathrm{O}$ argumento que embasou o aludido julgado é de que a finalidade da contribuição deve se relacionar ao contribuinte e não a atuação estatal em si, isto é, prescinde-se de uma referibilidade direta, narrada no primeiro caso, bastando a indireta, a que se refere a outra hipótese, para chancelar sua constitucionalidade ${ }^{128}$.

126 SCHOUERI, Luís Eduardo. Op. cit., p. 336-337.

127 BRASIL. Supremo Tribunal Federal. RE 635682/RJ. Relator: Min. Gilmar Mendes. Data de Julgamento: 25.04.2013. Data de Publicação: 24.05.2013. Disponível em: <http://stf.jusbrasil.com.br/jurisprudencia/23308019/recurso-extraordinario-re-635682-rj-stf/inteiro-teor-111675582>. Acesso em: 29 out. 2016.

128 PAULSEN, Leandro; VELLOSO, Andrei Pitten. Op. cit., p. 54 e 58. 
-. Tributação, direitos fundamentais e desenvolvimento

Vejamos trecho do voto proferido pelo relator Ministro Gilmar Mendes, em que, inclusive, se reporta a vários outros julgados que adotam o mesmo posicionamento:

De fato, as contribuições de intervenção no domínio econômico não exigem contraprestação direta em favor do contribuinte. Infundada, portanto, a alegação de que a contribuição somente deveria ser cobrada das categorias empresariais por ela beneficiadas. De acordo com a jurisprudência desta Corte, tratando-se de empresa que exerce atividade econômica, é devida a cobrança de contribuição para o SEBRAE. Por fim, registre-se novamente que o Supremo Tribunal Federal já se manifestou sobre as questôes discutidas no presente recurso extraordinário em diversas oportunidades. Cito, além do já mencionado RE 396.266, Rel. Min. Carlos Velloso, julgado pelo Plenário desta Corte, os seguintes precedentes: AI 650.194 AgR, Rel. Min. Ellen Gracie, Segunda Turma, DJe 28.8.2009; AI 604.712 AgR, Rel. Min. Ricardo Lewandowski, Primeira Turma, DJe 19.6.2009; RE 389.849 AgR, Rel. Min. Celso de Mello, Segunda Turma, DJe 12.6.2009; RE 576.659 ED, Rel. Min. Ellen Gracie, Segunda Turma, DJe 17.4.2009; RE 452.493 AgR, Rel. Min. Eros Grau, Segunda Turma, DJe 25.4.2008; RE 401.823 AgR, Rel. Min. Ayres Britto, Primeira Turma, DJ 11.2.2005. ${ }^{129}$

Contudo, notadamente em relação às contribuições destinadas ao custeio da seguridade social, quem assume papel de destaque é o princípio da solidariedade, dada a redação do artigo 195 da CRFB/88, segundo o qual "a seguridade social será financiada por toda a sociedade, de forma direta e indireta, nos termos da lei $(. . .)^{" 130}$. O dispositivo sugere que a seguridade social, sobretudo quanto à saúde e assistência social, é universal, possui uma referibilidade ampla, atinge a totalidade da população e, por isso, deve ser custeada por todos, mesmo as pessoas jurídicas que nunca se utilizarão dos serviços da seguridade ${ }^{131}$.

Barreto, contudo, ressalva que, para aplicação da solidariedade nas contribuições sociais, deve-se analisar "se aqueles traços mínimos reconhecidos para essa espécie tributária estão presentes" e se "a fonte de custeio total é compatível com o benefício ou serviço", sob pena de se aplicar a solidariedade até mesmo nos casos

129 BRASIL. Supremo Tribunal Federal. RE 635682/RJ, Relator: Min. Gilmar Mendes. Data de Julgamento: 25/04/2013. Data de Publicação: 24.05.2013 Disponível em: <http://stf.jusbrasil. com.br/jurisprudencia/23308019/recurso-extraordinario-re-635682-rj-stf/inteiro-teor-111675582>. Acesso em: 29 out. 2016.

130 PAULSEN, Leandro. Curso de direito tributário. 4. ed. Porto Alegre: Livraria do Advogado, 2012, p. 53.

131 Ibidem, p. 103. 
em que ela não se revela adequada e, pior, instituir contribuição em dissonância com o Ordenamento Constitucional ${ }^{132}$.

$\mathrm{O}$ aludido autor registra o que salta aos olhos: a solidariedade nas contribuiçôes sociais substitui a referibilidade típica das contribuiçôes de modo geral pela capacidade contributiva, já que toda a sociedade contribuirá, inobstante nem toda ela se beneficiar da atuação do Estado na Seguridade Social ${ }^{133}$.

O Supremo Tribunal Federal já se manifestou sobre a questão e consolidou o entendimento de que, pela solidariedade impregnada nas Contribuições Sociais, é legítimo figurar como contribuinte mesmo quem não está sujeito a se beneficiar da ação estatal. Merece destaque, nesse sentido, trecho do voto do Ministro Ricardo Lewandowski, relator no julgamento do RE 227.832/PR, in verbis:

De outra parte, anoto que o financiamento da Seguridade Social encontra arrimo no princípio da solidariedade. Esse fundamento foi bem explorado no RE 227.832/PR, cujo relator, o Ministro Carlos Velloso, valeu-se de uma interpretação sistemática para restringir o alcance do $₫ 3^{\circ}$ do artigo 155 da Constituição, em sua redação original, concluindo pela incompatibilidade entre o mencionado princípio e a concessão de imunidade no tocante a contribuiçôes sociais, no caso de empresas de grande porte, de mineração, de eletricidade, de telecomunicações e distribuidoras de derivados de petróleo. (...) Isso significa que, quando se cuida de reconhecer a imunidade relativamente a contribuições sociais, é preciso sempre sopesar valores, sendo escusado dizer que o valor solidariedade prepondera sobre qualquer outro de cunho econômico, visto estar ele diretamente referenciado ao postulado da dignidade humana, pilar sobre o qual se assenta o próprio arcabouço republicano. ${ }^{134}$

Passando-se adiante, no critério quantitativo da regra-matriz das contribuições, também encontramos uma base de cálculo muito semelhante à dos impos$\operatorname{tos}^{135}$, devendo sempre estar em acordo com o que a Constituição Federal permite que seja tributado, a exemplo dos artigos 149, $\$ 2^{\circ}$, III e 195, I a IV ${ }^{136}$.

132 BARRETO, Paulo Ayres. Contribuiçôes: regime jurídico, destinação e controle. São Paulo: Noeses, 2006, p. 133-136.

133 Ibidem, p. 134.

134 BRASIL. Supremo Tribunal Federal. RE 227.832/PR. Relator: Min. Ricardo Lewandowski. Data de Julgamento: 12.08.2010. Data de Publicação: 24.09.2010. Disponível em: <http:// redir.stf.jus.br/paginadorpub/paginador.jsp?docTP=AC\&docID=614536>. Acesso em: 29 out. 2016.

135 BARRETO, Paulo Ayres. Op. cit., p. 163-164.

136 PAULSEN, Leandro. Op. cit., p. 54. 
-. Tributação, direitos fundamentais e desenvolvimento

Quando analisamos a base de cálculo de uma contribuição isolando esse ponto específico do critério quantitativo de todos os demais componentes da regra-matriz, não é possível vislumbrar qualquer relação de quantificação dos gastos com a atividade para a qual foi instituída a contribuição ${ }^{137}$.

Se, contudo, o estudo da base de cálculo é aliado à lei instituidora que defina uma finalidade ao produto da arrecadação, infere-se que o montante cobrado é o dispêndio do Poder Público com a finalidade em questão equitativamente distribuída entre todos os contribuintes ${ }^{138}$.

Seguindo-se, ainda na exposição do critério quantitativo, sem nada de diferente em relação aos demais tributos, a alíquota das contribuições limita-se a dizer o quanto da base de cálculo representará a fatia subtraída pelo tributo ${ }^{139}$. Via de regra, em homenagem ao consagrado princípio da legalidade, os tributos - dentre eles, claro, as contribuições - só podem ter suas alíquotas majoradas através de lei promulgada com este fim ${ }^{140}$.

A Carta da República, no entanto, sobretudo vislumbrando a possibilidade de intervenção na economia, trouxe exceções ao princípio da legalidade, como ocorre com a Contribuição de Intervenção no Domínio Econômico prevista no artigo $177, \S 4^{\mathrm{o}}$, que pode ter sua alíquota diminuída e reestabelecida por ato do Executivo - resguardando-se que antes tenha a alíquota sido estabelecida por lei -, nos termos do artigo $177, \S 4^{\mathrm{o}}, \mathrm{I}, b$ da $\mathrm{CRFB} / 88^{141}$.

Nessa toada, é importante salientar que todas as contribuições, assim como os demais tributos, se submetem ao princípio da legalidade quanto à todos os critérios, considerando a importância deste na Ordem Constitucional vigente ${ }^{142} \mathrm{e}$ até mesmo por força do artigo 149, que faz alusão expressa ao artigo $150, \mathrm{I}^{143}$, ambos da $\mathrm{CRFB} / 88$. O princípio em comento implica, em síntese e principalmente, no fato de que somente podem ser exigidas contribuições previstas em lei e jamais de modo arbitrário pelo Poder Público.

137 BARRETO, Paulo Ayres. Op. cit., p. 165.

138 Ibidem, p. 165.

139 Ibidem, p. 165.

140 PAULSEN, Leandro; VELLOSO, Andrei Pitten. Op. cit., p. 80.

141 SCHOUERI, Luís Eduardo. Op. cit., p. 306-307.

142 PAULSEN, Leandro; VELLOSO, Andrei Pitten. Op. cit., p. 80.

143 BARRETO, Paulo Ayres. Op. cit., p. 127. 
$\mathrm{O}$ raciocínio de que a regra-matriz de incidência de tributo deve estar integralmente prevista na lei instituidora, por óbvio, se aplica às contribuiçōes ${ }^{144}$. A importância da legalidade está, também, em seu papel perante a finalidade a qual deve estar atrelada à instituição das contribuições, pois se a afetação da arrecadação da contribuição não estiver prevista em sua lei instituidora, haverá lesão ao princípio da legalidade, eis que restará proibido o recolhimento da contribuição por inexistir finalidade precisamente estabelecida - não estaremos diante de uma contribuição ${ }^{145}$.

Como é de se observar, a vinculação do produto da arrecadação, com base nos autores utilizados para exposição deste ponto específico, não encontra espaço na regra-matriz de incidência das contribuiçōes. Inobstante, é possível observar que a afetação influi no critério pessoal, sobretudo para definir o contribuinte, tendo em vista a referibilidade e a solidariedade estão intimamente relacionadas com a finalidade para a qual se cria a respectiva contribuição.

Nesse diapasão, voltaremos agora o olhar para a contribuição como espécie autônoma de tributo por força da vinculação do produto de sua arrecadação e, em seguida, veremos as consequências jurídicas da desvinculação da arrecadação.

\subsection{As contribuições como espécie autônoma de tributo}

Conforme já exposto exaustivamente no presente trabalho, grande parte da doutrina, à luz da atual Ordem Constitucional, entende que as contribuições são espécie tributária autônoma, distinta das demais sobretudo pela finalidade específica para a qual deve ser instituída, com a vinculação do produto de sua arrecadação a este fim particular.

Como bem salienta Barreto, há uma relação de causa e consequência entre o fim ao qual deve ser aplicada a arrecadação e o efetivo controle da destinaçãa ${ }^{146}$. Sem a verificação de uma finalidade constitucional autorizativa e a previsão expressa da destinação do produto da arrecadação a essa finalidade, parte da doutrina entende que a regra-matriz - e, consequentemente, a própria contribuição - seria inválida, com efeito ex tunc, ensejando, inclusive, a restituição ao contribuinte ${ }^{147}$.

\footnotetext{
144 SCHOUERI, Luís Eduardo. Op. cit., p. 292.

145 BARRETO, Paulo Ayres. Op. cit., p. 129.

146 Ibidem, p. 167.

147 Ibidem, p. 168-214.
} 
-. Tributação, direitos fundamentais e desenvolvimento

De modo semelhante, Velloso sustenta que a afetação do produto da arrecadação a uma finalidade específica é requisito de existência das contribuições. Se o legislador ao instituir um tributo estabelece que o numerário com ela arrecadado deve ser aplicado em determinada ação ou setor, estaremos diante de uma contribuição. A partir daí, considerando-se que a contribuição já existe, passa-se a análise de sua validade e constitucionalidade partindo-se da premissa de que os mandamentos constitucionais quando a competência e a finalidade devem, obviamente, ser observados ${ }^{148}$.

Significa dizer que, sem uma finalidade específica atrelada ao produto da arrecadação, não estaremos diante de uma contribuição. É possível que estejamos diante de um imposto ou de uma contribuição inconstitucional, mas não de uma contribuição válida ${ }^{149}$.

Não há, portanto, como concluir que a destinação da arrecadação é irrelevante para particularizar as contribuições. Se de um lado a afetação do produto da arrecadação não integra a regra-matriz das contribuições, por outro vimos que o que diferencia esta espécie tributária das demais é justamente a vinculação do montante arrecadado, de forma que a desvinculação abala a própria natureza das contribuiçōes $^{150}$.

Defende Velloso que, quando desafetadas, as contribuições passam por uma metamorfose jurídica e transformam-se em impostos. Tal conclusão é alcançada, segundo o autor, tendo em vista que a desafetação, em que pese não interferir em nada na regra-matriz de incidência das contribuições, acaba eliminando o ponto divergente entre esta espécie tributária e os impostos, fazendo que deixe de existir qualquer dissemelhança ${ }^{151}$.

A destinação do produto da arrecadação se revela de suma importância não apenas para dar autonomia às contribuições, mas também para diagnosticar a qual classe específica dentro da espécie contribuiçõos pertence aquela em especial - se

PAULSEN, Leandro; VELlOSO, Andrei Pitten. Op. cit., p. 49-50.

149 Ibidem, p. 34.

150 GOMES, Flávia Helena. Das implicações tributárias do desvio de finalidade na destinação do produto arrecadado com a CIDE-Combustíveis. Revista do Direito Público, v. 3, n. 3, p. 144$162,2008$.

151 PAULSEN, Leandro; VELLOSO, Andrei Pitten. Op. cit., p. 61. 
social, de intervenção no domínio econômico ou de interesse de categoria profissional ou econômica ${ }^{152}$.

Isso porque as contribuições não são unas, mas se dividem em categorias diversas, conforme apregoa Velloso, de forma que temos as contribuições sociais, cujo produto da arrecadação é direcionado à atuação do Poder Público na área social, sobretudo na seguridade social; as contribuições de intervenção na economia, destinadas à atuação do Estado no domínio econômico, e as contribuições de interesse das categorias profissionais ou econômicas, cuja vinculação da arrecadação é direcionada a proteção dos interesses de categoria profissional ou econômica específica ${ }^{153}$.

Não são apenas os autores utilizados no presente trabalho que defendem a autonomia das contribuições. O Supremo Tribunal Federal já se manifestou nesse sentido, como no voto do Ministro Joaquim Barbosa, relator no julgamento conjunto das ADI's 2.556 e 2.558, cujo trecho merece ser transcrito:

(...) esta Suprema Corte considera constitucionais ambas as contribuiçôes criadas pela LC 110/2001 (...). Os dois tributos tinham por objetivo custear os dispêndios da União decorrentes de decisão do STF, que considerou devido o reajuste dos saldos do FGTS (RE 226.855, rel. min. Moreira Alves, Pleno, DJ de 13-10-2000). As restriçôes previstas nos arts. 157, II, e 167, IV, da Constituição são aplicáveis aos impostos, e, no caso em exame, trata-se da espécie tributária contribuição, nitidamente caracterizada pela prévia escolha da destinação específica do produto arrecadado. ${ }^{154}$

Adentrando-se ainda mais na afetação do produto da arrecadação, Velloso salienta que as contribuições devem ser necessárias. Isto é, se a União institui uma contribuição no pretexto de aplicar a arrecadação em determinado fim, se esse fim se extingue ou se torna desnecessária, a continuação da cobrança permitiria ajuizamento de ação de repetição de indébito ${ }^{155}$.

Apresentando tese inovadora, Domingues sustenta que a vinculação finalística das contribuições, além de garantir a elas autonomia, é um encargo do Poder Público, sendo este entendido como um norma acessória à regra-matriz de incidência,

\footnotetext{
152 Ibidem, p. 34.

153 Ibidem, p. 59.

154 BRASIL. Supremo Tribunal Federal. ADI 2.556 e ADI 2.568. Relator: Min. Joaquim Barbosa. Data de Julgamento: 13.06.2012. Data de Publicação: 20.09.2012. Disponível em: <http:// www.stf.jus.br/portal/constituicao/artigoBd.asp? item=1634>. Acesso em: 26 nov. 2016.

155 PAULSEN, Leandro; VELLOSO, Andrei Pitten. Op. cit., p. 52.
} 
•• Tributação, direitos fundamentais e desenvolvimento

que também possui um antecedente - $\mathrm{o}$ ingresso do tributo aos cofres públicos - e um consequente - dever de aplicação da arrecadação na finalidade a que é vinculada a contribuição. Assim, esse encargo também seria um acessório, no plano fático, da relação jurídico-tributária formada no caso concreto ${ }^{156}$.

\subsection{Conclusões parciais}

De todo o exposto até o momento, é forçoso concluir que (i) as contribuições possuem regra-matriz de incidência com a mesma estrutura dos demais tributos que pode, inclusive, ser idêntica à de algum imposto ou até mesmo de taxa; (ii) são espécie tributária autônoma que se diferenciam dos impostos apenas pela afetação do produto de sua arrecadação à finalidade específica prevista na Constituição Federal e na lei instituidora, motivo pelo qual mesmo que (iii) a vinculação finalística do produto arrecadado, segundo entendimento majoritário, não componha a regra-matriz de incidência das contribuições, inobstante influenciar na sua formação - como no caso de definir quem serão os contribuintes tendo por conta a referibilidade -, (iv) macula de inconstitucionalidade a lei que instituir uma contribuição sem observar finalidade estabelecida pela Constituição Federal.

A matéria, contudo, não se esgota com essas conclusões. Ao contrário, nos leva a refletir quais os efeitos da destinação do produto arrecadado à finalidade diversa daquela que é constitucional e legalmente pretendida por intermédio de previsão em lei orçamentária ou ainda pelo Poder Constituinte Derivado, com destaque para a Desvinculação de Receitas da União (DRU), cuja principal receita advém da desvinculação finalística das contribuiçôes sociais e de intervenção no domínio econômico. Tudo isso será tratado a seguir.

\section{OS EFEITOS JURÍDICOS DA DESVINCULAÇÃO DO PRODUTO DA ARRECADAÇÃO DAS CONTRIBUIÇÕES}

A desvinculação finalística das contribuições produz efeitos variados. Conforme exposto anteriormente, se a norma instituidora da contribuição justifica sua cobrança com destinação da arrecadaçãao à finalidade não prevista na Constituição, a norma instituidora estará eivada de inconstitucionalidade e a contribuição será inválida.

156 DOMINGUES, Gabriel Demetrio. Op. cit., p. 73. 
O orçamento público, que prevê receitas e despesas da Administração, é submetido a controle, este encarregado pela Constituição Federal ao Poder Legislativo, nos termos de seu artigo 70. O controle orçamentário visa justamente evitar que o Administrador Público promova alocação de recursos em dissonância do que estabelece as normas orçamentárias, inclusive responsabilizando os agentes públicos pelos crimes cometidos quando são desobedecidas a Lei e a Constituição para tredestinar o produto da arrecadação das contribuições ${ }^{157}$.

Nesse contexto, questão de extrema relevância é a desvinculação do produto da arrecadação das contribuições prevista em lei orçamentária ou, ainda, em norma constitucional inserida no Ordenamento por meio de Emenda Constitucional, como ocorre com a Desvinculação de Receitas da União (DRU). Isto é, o editor da norma orçamentária e o constituinte derivado desvinculam a arrecadação das contribuições da finalidade prevista na Constituição Federal e, consequentemente, na norma instituidora da contribuição - quando esta última é editada em consonância com a Carta Política.

É dessa desvinculação - pelo editor da norma orçamentária e pelo constituinte derivado - que nos ocuparemos agora.

\subsection{A desvinculação da arrecadação das contribuições e o orçamento público}

O orçamento público é a previsão de receitas e despesas da Administração Pública e representa uma programação de como será o quadro econômico e financeiro do ente em determinado período de tempo ${ }^{158}$, formando um todo unitário ${ }^{159}$, vinculando a atuação do administrador público ${ }^{160}$.

Mais do que isso, Oliveira salienta que, modernamente, o orçamento ganhou forte cunho político, já que através dele o Estado intervém no domínio econômico e fixa suas metas ${ }^{161}$, que representam o plano dos Governantes que ocupam o poder no momento, indicando quais setores são prioridade na alocação de recursos ${ }^{162}$.

\footnotetext{
BARRETO, Paulo Ayres. Op. cit., p. 182-193.

58 BARRETO, Paulo Ayres. Op. cit., p. 187.

159 Ibidem, p. 189.

160 OLIVEIRA, Régis Fernandes de. Op. cit., p. 405.

161 Ibidem, p. 401.

162 Ibidem, p. 404.
} 
-. Tributação, direitos fundamentais e desenvolvimento

$\mathrm{O}$ orçamento manifesta aspecto político quando prevê o funcionamento da máquina pública de modo a atender mais a determinados grupos do que outros ou resolver problemas em escala de necessidade que varia conforme há troca de gestão e aflora o aspecto jurídico por se tratar de ato da Administração, lei cujo fundamento de validade se extrai diretamente da Constituição ${ }^{163}$. Ainda, o orçamento manifesta aspecto econômico por representar a política fiscal e refletir a conjuntura econômica, assim como apresenta aspecto técnico por necessitar de elaboração de contas e análise de normas para que seja elaborado em consonância com as determinações legais e constitucionais ${ }^{164}$.

Nos termos do artigo 165 da Constituição Federal, o orçamento público, em homenagem ao princípio da exclusividade ${ }^{165}$ não pode conter matéria diversa de previsão de receitas e fixação de despesas e estas, pelo princípio da universalidade orçamentária, precisam estar todas incluídas no orçamento ${ }^{166}$, compreendendo, inclusive, o orçamento próprio da seguridade social ${ }^{167}$. A Lei Orçamentária deve ser anual, conforme artigo 165, III da CRFB/88 e deve respeito à Lei de Diretrizes Orçamentárias, que por sua vez observa o Plano Plurianual. Todos esses diplomas se relacionam intimamente e formam um sistema orçamentário ${ }^{168}$.

Sinteticamente, o plano plurianual, previsto no artigo $165, \$ 1^{\circ} \mathrm{da} C R F B / 88$, é uma lei em sentido formal, que dispóe as metas que serão perseguidas pelo Governo durante seus quatro anos de vigência, influenciando, inclusive, a produção das demais normas orçamentárias ${ }^{169}$. A Lei de Diretrizes Orçamentárias traz as prioridades do Estado; é um plano preliminar que antecede a Lei Orçamentária Anual e orienta a elaboração desta e traça disposições sobre alteração na legislação tributária $^{170}$. A Lei Orçamentária, por sua vez, observa as outras duas normas orçamentárias e traz, de forma mais minuciosa os planos e metas definidas ${ }^{171}$.

O Ordenamento Constitucional converge para o equilíbrio orçamentário. Em interessante passagem, Baleeiro destaca que o ao longo da história, inclusive

163 BALEEIRO, Aliomar. Op. cit., p. 411.

164 Ibidem, p. 412.

165 CASTELLANI, Fernando F. Op. cit., p. 166.

166 Ibidem, p. 164.

167 BARRETO, Paulo Ayres. Op. cit., p. 187.

168 CASTELLANI, Fernando F. Op. cit., p. 156.

169 Ibidem, p. 157.

170 Ibidem, p. 158.

171 Ibidem, p. 159. 
de países como os Estados Unidos, o orçamento público foi marcado por déficit, dada necessidade de gastar dinheiro do Estado para investir em diversos setores, sobretudo na prestação de serviços públicos essenciais, com vistas a atingir o desenvolvimento nacional ${ }^{172}$. Disso, extrai-se a ideia de que cabe também ao Administrador Público utilizar o orçamento para equilibrar a economia, planejando receitas e despesas de modo a contribuir para mantê-la instável. O autor ressalva, contudo, que essa interpretação é fragilizada quando observamos que ela pode ser invocada para subsidiar demagogias e más administraçôes, o que, por certo, não deve ser admitido ${ }^{173}$.

Feito esse adendo, aponta-se que a Constituição Federal estabelece diversas regras que devem ser seguidas pelos legisladores na elaboração das normas que versam sobre o orçamento, com vistas a manter sempre um equilíbrio orçamentário nas contas públicas, em atendimento ao princípio do equilíbrio ${ }^{174}$. É o caso, por exemplo, do artigo 167, VIII que veda a utilização de recursos da seguridade social para cobrir déficit de empresas, fundações ou fundos ${ }^{175}$.

Nessa mesma linha, estabelece o artigo 167, nos incisos IV e XI da CRFB/88, que não é possível vincular a arrecadação de impostos a receitas específicas ${ }^{176}$, bem como é impossível dar à arrecadação auferida com as contribuições sociais incidentes sobre remuneração paga por empregador e sobre rendimentos de trabalhadores e segurados, destinação diversa do custeio da seguridade ${ }^{177}$, respectivamente ${ }^{178}$.

O inciso IV tem claro objetivo de evitar o engesso da Administração Pública e permitir que o administrador tenha disponibilidade financeira para atuar no que

172 BALEEIRO, Aliomar. Op. cit., p. 427.

173 Ibidem, p. 428.

174 CASTELLANI, Fernando F. Op. cit., p. 162.

175 BARRETO, Paulo Ayres. Op. cit., p. 191.

176 BARRETO, Paulo Ayres. Op. cit., p. 192.

177 CASTELLANI, Fernando F. Op. cit., p. 170.

178 Art. 167. São vedados: (...) IV - a vinculação de receita de impostos a órgão, fundo ou despesa, ressalvadas a repartição do produto da arrecadação dos impostos a que se referem os arts. 158 e 159, a destinação de recursos para as ações e serviços públicos de saúde, para manutenção e desenvolvimento do ensino e para realização de atividades da administração tributária, como determinado, respectivamente, pelos arts. 198, $\$ 2^{\circ}, 212$ e 37, XXII, e a prestação de garantias às operaçōes de crédito por antecipação de receita, previstas no art. $165, \$ 8^{\circ}$, bem como o disposto no $\$ 4^{\circ}$ deste artigo; (...) XI - a utilização dos recursos provenientes das contribuições sociais de que trata o art. 195, I, a, e II, para a realização de despesas distintas do pagamento de benefícios do regime geral de previdência social de que trata o art. 201. 
•• Tributação, direitos fundamentais e desenvolvimento

for necessário ${ }^{179}$. Nota-se, contudo, que, conforme afirma Castellani, a vedação se restringe aos impostos, sendo plenamente possível que as demais espécies tributárias sejam afetadas ${ }^{180}$, como são as contribuições.

Dessa forma, segundo já mostrado no presente trabalho, a arrecadação das contribuições deve ser direcionada a atuação estatal que ensejou sua instituição e a proibição de vinculação dos impostos é um contraponto à necessária vinculação das contribuiçōes de modo a estabelecer um equilíbrio entre produto da arrecadação dos tributos não afetados e dos tributos afetados, sem engessar o Estado ${ }^{181}$.

O inciso XI veda que o produto da arrecadação de todas as contribuiçõoes sociais do empregador incidente sobre a folha de salários e do trabalhador previstas no artigo 195, I, a e II da CRFB/88, respectivamente, seja destinado a outra finalidade que não seja o pagamento de benefícios do regime geral da previdência social. Isto é, de modo algum podem figurar no orçamento fiscal, que engloba as despesas em geral da União e, menos ainda, no orçamento de investimentos, que se reporta à atuação do Estado por meio de empresas públicas e sociedade de economia mista ${ }^{182}$.

Tudo isto significa, também, que, do mesmo modo que o Estado precisa de dinheiro para atender às necessidades da população na prestação de serviços públicos e até mesmo honrar suas dívidas, o povo, que figura no polo passivo da relação jurídico-tributária, tem o direito de pagar tributos de forma razoável, com observância das limitações e vinculações constitucionais ${ }^{183}$.

O direito a uma tributação justa é elevado por alguns juristas ao patamar de direito fundamental implícito da Constituição, a exemplo do que afirma Elizabete Rosa de Mello. Segundo a autora, o contribuinte tem o direito de ser informado de forma transparente a respeito dos parâmetros utilizados para cobrança e cálculo do tributo, bem como sobre os motivos ensejadores da tributaçãa ${ }^{184}$. Isso porque os contribuintes se desfazem de uma parte de seu patrimônio para entrega-la ao Estado a fim de obter a satisfação das necessidades públicas; é uma ideia que decorre do

\footnotetext{
BARRETO, Paulo Ayres. Op. cit., p. 192.

${ }^{80}$ CASTELLANI, Fernando F. Op. cit., p. 167.

181 BARRETO, Paulo Ayres. Op. cit., p. 192.

182 Ibidem, p. 175-177.

183 BARRETO, Paulo Ayres. Op. cit., p. 154.

${ }^{184}$ MELLO, Elizabete Rosa de. Direito fundamental a uma tributação justa. São Paulo: Atlas, 2013, p. 22.
} 
próprio regime democrático, em que os representantes do povo são eleitos para servir à população e governar com sua chancela ${ }^{185}$.

A ideia do Estado Democrático de Direito exige que o Poder Público seja transparente com a população e divulgue as informaçôes com clareza para serem compreendidas por todos, independentemente do nível de escolaridade ${ }^{186}$, bem como garante que haja reserva de receita para custeio dos serviços prestacionais do Estado referentes à consolidação de direitos fundamentais, mormente os direitos sociais $^{187}$. De igual modo, os contribuintes precisam ver seu dinheiro entregue na forma de tributos sendo utilizados racionalmente em seu benefício e sobrepor os direitos fundamentais mais urgentes e que mais agonizam sobre aqueles menos urgentes ${ }^{188}$. Nesse cenário, o orçamento funciona como uma garantia da população para controle dos gastos do Estado ${ }^{189}$.

Seguindo-se essa perspectiva, Barreto destaca que, sendo a vinculação do produto da arrecadação o que faz das contribuições espécie tributária autônoma, a previsão da desvinculação em norma orçamentária é completamente incompatível com essa espécie tributária e compromete sua autonomia ${ }^{190}$, além de prejudicar seu papel de efetivação de direitos.

Muito se discutiu a possibilidade de apreciação da constitucionalidade de lei orçamentária. O STF, no julgamento da ADI 1.937-MC, decidiu que a lei orçamentária, por ser ato normativo de efeitos concretos editado pelo Poder Público sob a forma de lei, não era passível de ser objeto de controle abstrato de constitucionalidade, pois faltava-lhe abstração ou generalidade ${ }^{191}$.

Contudo, no ano de 2008, no julgamento da ADI 4.048-DF, a Suprema Corte manteve a mudança de posicionamento já ventilada no bojo da ADI 2925-DF,

185 Ibidem, p. 22.

186 Ibidem, p. 35.

187 BREYNER, Frederico Menezes. Inconstitucionalidade da Desvinculação das Receitas da União (DRU) quanto às contribuições sociais sob a ótica dos direitos prestacionais fundamentais. Revista do Centro Acadêmico Afonso Pena, v. 9, n. 1, 2006, p. 216.

188 MELLO, Elizabete Rosa de. Op. cit., p. 41.

189 CASTELLANI, Fernando F. Op. cit., p. 155.

190 BARRETO, Paulo Ayres. Op. cit., p. 194.

191 ENCARNAÇÃO, Iasmine Souza. O STF e o orçamento: controle de constitucionalidade das leis orçamentárias. Disponível em: <http://www.ambito-juridico.com.br/site/?n_link=revista_artigos_leitura\&artigo_id=14376>. Acesso em: 4 nov. 2016. 
julgada no ano de 2004, para acolher a possibilidade de declarar a inconstitucionalidade de lei orçamentária em sede de controle abstrato, sob o argumento de que, como extrai seu fundamento de validade diretamente da Constituição Federal, não é possível admitir que a lei orçamentária, ainda que seja lei em sentido formal, não seja objeto de controle constitucionalidade, consoante se lê na ementa jurisprudencial in verbis:

O Tribunal iniciou julgamento de ação direta proposta pelo Partido da Social Democracia Brasileira - PSDB em que se pleiteia a declaração da inconstitucionalidade da Medida Provisória 405/2007, que abre crédito extraordinário, em favor da Justiça Eleitoral e de diversos órgãos do Poder Executivo. Preliminarmente, o Tribunal, por maioria, conheceu da ação, por entender estar-se diante de um tema ou de uma controvérsia constitucional suscitada em abstrato - independente do caráter geral ou específico, concreto ou abstrato de seu objeto - de inegável relevância jurídica e política, que deveria ser analisada a fundo. Asseverou-se que os atos do Poder Público sem caráter de generalidade não se prestam ao controle abstrato de normas, eis que a própria Constituição adotou como objeto desse processo os atos tipicamente normativos, ou seja, aqueles dotados de um mínimo de generalidade e abstração. Considerou-se, entretanto, que outra deveria ser a interpretação no caso de atos editados sob a forma de lei. Ressaltou-se que essas leis formais decorreriam ou da vontade do legislador ou do próprio constituinte, que exigiria que certos atos, mesmo que de efeito concreto, fossem editados sob a forma de lei. Assim, se a Constituição submeteu a lei ao processo de controle abstrato, meio próprio de inovação na ordem jurídica e instrumento adequado de concretização da ordem constitucional, não seria admissível que o intérprete debilitasse essa garantia constitucional, isentando um grande número de atos aprovados sob a forma de lei do controle abstrato de normas e, talvez, de qualquer forma de controle. Aduziu-se, ademais, não haver razôes de índole lógica ou jurídica contra a aferição da legitimidade das leis formais no controle abstrato de normas, e que estudos e análises no plano da teoria do direito apontariam a possibilidade tanto de se formular uma lei de efeito concreto de forma genérica e abstrata quanto de se apresentar como lei de efeito concreto regulação abrangente de um complexo mais ou menos amplo de situações. Concluiu-se que, em razão disso, o Supremo não teria andado bem ao reputar as leis de efeito concreto como inidôneas para o controle abstrato de normas. Vencido, no ponto, o Min. Cezar Peluso que não conhecia da ação, por reputar não se tratar no caso de uma lei, sequer no aspecto formal. ${ }^{192}$

Esse entendimento foi, inclusive, repetido pelo STF em recente julgado, cuja ementa segue abaixo:

192 BRASIL. Supremo Tribunal Federal. ADI 4048 MC/DF. Relator: Min. Gilmar Mendes, Data de julgamento: 17.04.2008. Data de Publicação: 30.04.2008. Disponível em: <http://www. stf. jus.br/arquivo/informativo/documento/informativo502.htm>. Acesso em: 23 out. 2016. 
Decisão: 1. Trata-se de ação direta de inconstitucionalidade, com pedido de medida cautelar, promovida pelo Partido da Social Democracia Brasileira - PSDB para impugnar a validade constitucional da Medida Provisória 402/2007, que abriu créditos extraordinários para diversos órgãos do Poder Executivo para atender às programaçôes constantes dos Anexos I e III do referido ato normativo (fls. 11-36). (...) O Presidente da República (...) aduziu que se trata de ato normativo de efeito concreto, não sindicável na via da ação direta de inconstitucionalidade. (...) Em 5 de novembro de 2008, o Tribunal Pleno deferiu a medida cautelar em acórdão assim ementado: CONSTITUCIONAL. MEDIDA CAUTELAR EM AÇÃO DIRETA DE INCONSTITUCIONALIDADE. MEDIDA PROVISÓRIA N. 402, DE 23 DE NOVEMBRO DE 2007, CONVERTIDA NA LEI N. 11.656, DE 16 DE ABRIL DE 2008. ABERTURA DE CRÉDITO EXTRAORDINÁRIO. AUSÊNCIA DOS REQUISITOS CONSTITUCIONAIS DA IMPREVISIBILIDADE E DA URGÊNCIA ( $\$ 3^{\circ}$ DO ART. 167 DA CF), CONCOMITANTEMENTE. 1. A lei não precisa de densidade normativa para se expor ao controle abstrato de constitucionalidade, devido a que se trata de ato de aplicação primária da Constituição. Para esse tipo de controle, exige-se densidade normativa apenas para o ato de natureza infralegal. Precedente: ADI 4.048-MC. (...) 3. A jurisprudência desta Corte é pacífica quanto à prejudicialidade da ação direta de inconstitucionalidade por perda superveniente de objeto, que tanto pode decorrer da revogação pura e simples do ato impugnado como do exaurimento de sua eficácia. Precedentes. 4. Não é passível o recebimento dessa ação como ação de descumprimento de preceito fundamental, uma vez que não subsistem quaisquer efeitos jurídicos a serem regulados. 5 . Agravo regimental não provido. (ADI 4041 AgR-AgR-AgR, Relator (a): Min. DIAS TOFFOLI, Tribunal Pleno, julgado em 24/03/2011, DJe de 14/06/2011) A mesma conclusão há de se impor no presente caso. 3. Ante o exposto, julgo extinto o processo sem resolução do mérito, com base nos arts. 21, IX, do RISTF e 267, VI, do Código de Processo Civil. Publique-se. Intime-se. Brasília, 10 de março de 2016. Ministro Teori Zavascki Relator Documento assinado digitalmente. ${ }^{193}$ (grifado)

Soa correto o atual entendimento, sobretudo por ser deveras temerário supor que a lei orçamentária não pode ser objeto de controle abstrato, afinal, isso seria o mesmo que dizer que essa norma está acima da Carta Política ${ }^{194}$.

Nesse contexto, sustenta Barreto que a lei orçamentária que rompe o vínculo entre causa da contribuição e produto da arrecadação "desnatura a exigência, abre ao contribuinte a possibilidade de repetir o indébito tributário", já que o montante

193 BRASIL. Supremo Tribunal Federal. ADI 4049. Relator: Min. Teori Zavascki. Data de Julgamento: 10.03.2016. Data da Publicação: 16.03.2016. Disponível em: <http://stf.jusbrasil. com.br/jurisprudencia/321786934/acao-direta-de-inconstitucionalidade-adi-4049-df-distrito-federal-0001092-0320080010000 >. Acesso em: 16 out. 2016.

194 CASTELLANI, Fernando F. Op. cit., p. 207. 
•• Tributação, direitos fundamentais e desenvolvimento

não foi aplicado no fim que deveria e, por isso, se tornou um pagamento indevido feito pelo contribuinte ${ }^{195}$.

$\mathrm{O}$ autor defende ainda, que, todo o montante que o contribuinte viria a recolher aos cofres públicos pode deixar de ser recolhido - em outras palavras, o contribuinte não precisa pagar a contribuição - caso a lei orçamentária preveja a desvinculação do produto da arrecadação. $O$ valor em tese devido se tornaria um indébito e, assim sendo, não há que ser recolhido ${ }^{196}$.

Não apenas pelas minuciosas previsões constitucionais, o posicionamento de Barreto se respalda no artigo $8^{\circ}$, parágrafo único da Lei Complementar n. 101/2000, Lei de Responsabilidade Fiscal (LRF), segundo o qual os recursos públicos vinculados a finalidade específica devem, necessariamente, ser usados para este respectivo fim ${ }^{197}$.

Também por conta da vinculação da arrecadação das contribuições que é verdadeiro fator que confere autonomia a esta espécie tributária, Castellani sustenta que não é "razoável supor que um enunciado constitucional expresso determinasse a importância da destinação, para ser completamente ignorado em sua materialização na lei orçamentária" ${ }^{198}$. Se a lei orçamentária anual prever a desvinculação da arrecadação das contribuições, impossível é a cobrança do tributo ${ }^{199}$.

Prosseguindo, o autor salienta que todas as normas orçamentárias devem seguir a vinculação do produto arrecadado com as contribuições, sendo, inclusive, inadmissível a justificativa de que o orçamento, como objeto de estudo mais atinente ao direito financeiro, não deve sofrer influência das normas direito tributário, uma vez que ambos os ramos do direito estão entrelaçados e os tributos, como receita pública por excelência que são, obrigam a ciência das finanças a respeitar sua regulamentação ${ }^{200}$.

Muito interessante, também, a tese suscitada por Castellani de que, com fulcro no direito fundamental a propriedade, previsto no artigo $5^{\circ}$, XXII da CRFB/88, os contribuintes somente podem ser privados de bem de sua propriedade, in casu,

BARRETO, Paulo Ayres. Op. cit., p. 195.

196 BARRETO, Paulo Ayres. Op. cit., p. 202.

197 BARRETO, Paulo Ayres. Op. cit., p. 201.

198 CASTELLANI, Fernando F. Op. cit., p. 171.

199 Ibidem, p. 193.

200 Ibidem, p. 172. 
o dinheiro dispendido com o pagamento das contribuições, se a finalidade que fundamenta a criação do tributo for devidamente respeitada. Caso contrário, torna-se ilegítimo o tributo ${ }^{201}$.

Destaca o autor em comento que as contribuiçõos de categorias profissionais ou econômicas não entram em orçamento quando recolhidas por pessoas jurídicas às quais foi delegada capacidade tributária ativa e, caso a própria União se incumbisse dessa tarefa, deveriam constar no orçamento fiscal direcionada a finalidade que lhe é própria. As contribuições de iluminação pública, por sua vez, entram no orçamento do Município e devem ser destinadas a custeio da iluminação públi$\mathrm{Ca}^{202}$. Mesma ideia se dirige às contribuiçōes de intervenção no domínio econômico que, segundo defende Castellani, devem compor orçamento fiscal em atividades colimadas ao fim que as fundamenta ${ }^{203}$.

Seguindo o viés doutrinário que se posiciona em desfavor da desvinculação da arrecadação das contribuiçôes, Velloso aponta que, da mesma forma que a lei instituidora das contribuições deve respeitar a vinculação do produto da arrecadação, as normas orçamentárias também devem seguir a rigor esses parâmetros constitucionais, bem como o artigo $8^{\circ}$, parágrafo único da Lei de Responsabilidade Fiscal, já mencionado no presente trabalho ${ }^{204}$. A contribuição e sua lei instituidora serão constitucionais, mas à norma orçamentária faltará a constitucionalidade ${ }^{205}$.

Conforme Velloso, ainda, a desvinculação é ilegítima mesmo quando a norma orçamentária prevê desvinculação apenas parcial, impedindo mesmo a própria cobrança do tributo considerando que não haverá incidência da contribuição na medida do desvio. Sustenta, também, que caso a contribuição seja recolhida aos cofres públicos, haverá indébito restituível aos contribuintes ${ }^{206}$.

O Supremo Tribunal Federal, ao se debruçar sobre a questão no julgamento da ADI 2925-DF, decidiu que a Lei Orçamentária deve sim respeitar a finalidade justificadora da criação de Contribuição de Intervenção no Domínio Econômico estabelecida pela Constituição Federal, conforme se observa na ementa in verbis:

\footnotetext{
201 Ibidem, p. 173.

202 Ibidem, p. 177.

203 CASTELLANI, Fernando F. Op. cit., p. 178.

204 PAULSEN, Leandro; VELLOSO, Andrei Pitten. Op. cit., p. 70.

205 Ibidem, p. 69 e 71.

206 Ibidem, p. 71.
} 
•• Tributação, direitos fundamentais e desenvolvimento

CIDE-Combustíveis: Destinação dos Recursos. Prosseguindo no julgamento iniciado em 11.12.2003 (v. Informativo 333), o Tribunal, por considerar que o dispositivo impugnado admitiria interpretação abrangente ou ambígua, por maioria, julgou procedente em parte o pedido formulado em ação direta ajuizada pela Confederação Nacional do Transporte - CNT para emprestar ao art. 4o, I, a, b, c, e d, da Lei 10.640/2003, Lei Orçamentária Anual da União, interpretação conforme a Constituição, no sentido de que a abertura de crédito suplementar deve ser destinada às três finalidades enumeradas no art. $177, \$ 4^{\circ}, \mathrm{II}, \mathrm{a}, \mathrm{b}$ e c, da CF/88 ("A lei que instituir contribuição de intervenção no domínio econômico relativa às atividades de importação ou comercialização do petróleo e seus derivados ... deverá atender aos seguintes requisitos: ... II - os recursos arrecadados serão destinados: a) ao pagamento de subsídios a preços ou transporte de álcool combustivel, gás natural e seus derivados ou derivados de petróleo; b) ao financiamento de projetos ambientais relacionados com a indústria do petróleo e do gás; c) ao financiamento de programas de infraestrutura de transportes"). Ressaltou-se, na espécie, que o provimento parcial do pedido não implicou qualquer intervenção nos atos políticos do Poder Executivo, mas apenas a estrita observância do disposto na Constituição. Vencidos os Ministros Ellen Gracie, relatora, Joaquim Barbosa, Nelson Jobim e Sepúlveda Pertence, que julgavam improcedente o pedido, por entenderem que a limitação decorrente do contingenciamento de recursos imposta na Lei 10.640/2003 não importou em desvio de finalidade ou ofensa à Constituição, inclusive em face da previsão expressa nela contida, no sentido da necessidade de observância do disposto no parágrafo único do art. $8^{\circ}$ da Lei de Responsabilidade Fiscal — segundo o qual os recursos vinculados a finalidades específicas serão exclusivamente para atender o objeto de sua vinculação, ainda que em exercícios posteriores. ${ }^{207}$ (grifado)

Apesar de ser evidente, cumpre salientar que, se uma norma orçamentária não pode dispor da desvinculação da arrecadação das contribuições, menos ainda poderá o fazer uma norma não orçamentária, que, segundo Velloso, de igual modo provocará a não incidência da contribuição eximindo o contribuinte de pagamento $^{208}$. O ex-Ministro do Supremo Tribunal Federal Carlos Velloso já se manifestou nesse sentido quando ainda integrava a Corte no julgamento do RE 183.906, de relatoria do Ministro Marco Aurélio, em trecho de seu voto que merece ser transcrito, embora o Ministro tenha sido vencido por posicionamento divergente quanto a outro ponto em análise no julgado:

207 BRASIL. Supremo Tribunal Federal. ADI 2.925. Relator: Rel. Orig. Min. Ellen Gracie, Rel. p/ o Acórdão Min. Marco Aurélio. Data de Julgamento: 19.12.2003. Data de Publicação: 13.02.2004. Disponível em: <http://www.stf.jus.br//arquivo/informativo/documento/informativo334.htm>. Acesso em: 23 out. 2016.

208 PAULSEN, Leandro; VELLOSO, Andrei Pitten. Op. cit., p. 69. 
Uma ressalva é preciso ser feita. É que caso há, no sistema tributário brasileiro, em que a destinação do produto da arrecadação do tributo diz com a legitimidade deste e, por isso, não ocorrendo a destinaçáo constitucional do mesmo, surge para o contribuinte o direito de não pagá-lo. Refiro-me às contribuiçóes parafiscais - sociais, de intervenção no domínio econômico e de interesse de categorias profissionais ou econômicas, C.F., art. 149 - e aos empréstimos compulsórios (CF, art. 148). Leciona Misabel Abreu Machado Derzi que a "Constituição de 1988, pela primeira vez, cria tributos finalisticamente afetados, que são as contribuições e os empréstimos compulsórios, dando à destinação que lhe é própria relevância não apenas do ponto de vista do Direito Financeiro ou Administrativo, mas igualmente de Direito Tributário.” E acrescenta a ilustre professora da UFMG, que "o contribuinte pode opor-se à cobrança de contribuição que não esteja afetada aos fins, constitucionalmente admitidos; (...) $)^{209}$ (grifado).

Desse modo, é cediço concluir, conforme doutrina e jurisprudência predominantes atualmente, não pode a lei orçamentária desobedecer os parâmetros constitucionais de vinculação da arrecadação das contribuições, sob pena de se revelar inconstitucional e subtrair das contribuições justamente o aspecto que lhes garante autonomia.

É prudente, por via de consequência, rechaçar a desvinculação do produto da arrecadação das contribuições feita pelo legislador ordinário, inclusive o orçamentário. A questão se complica, contudo, quando a desvinculação advém do próprio texto constitucional inserido por meio de Emendas Constitucionais. É o que veremos a seguir.

\subsection{A desvinculação da arrecadação das contribuições pelo poder constituinte derivado. A desvinculação de receitas da União.}

Como visto, o legislador infraconstitucional, ao desvincular o produto da arrecadação das contribuições, descaracteriza o tributo e macula de inconstitucionalidade a norma. No entanto, o debate se enriquece ainda mais quando a desvinculação advém de texto constitucional, por conta do trabalho do constituinte derivado reformador. É o que ocorre com a Desvinculação de Receitas da União (DRU).

O cerne da pretensão de desvinculação trazida pela DRU foi instituído, originalmente, em 1994, sob a forma de um Fundo Social de Emergência (FSE), inse-

209 BRASIL. Supremo Tribunal Federal. RE 183.906. Relator: Min. Marco Aurélio. Data de Julgamento: 18.09.1997. Data de Publicação: 29.09.1997. Disponível em: <http://redir.stf.jus. br/paginadorpub/paginador.jsp?docTP=AC\&docID=227617>. Acesso em: 16 out. 2016. 
•• Tributação, direitos fundamentais e desenvolvimento

rido nos artigos 71 a 73 do Ato das Disposiçōes Constitucionais Transitórias pela Emenda Constitucional de Revisão n. 1/1994, com previsão expressa no texto constitucional para vigorar durante os exercícios de 1994 e 1995, sob o argumento de que ajudaria a aumentar a margem de discricionariedade do Governo na alocação de recursos e permitir superávit nas contas públicas de modo a contribuir para a estabilização da economia impactada com o advento do Plano Real ${ }^{120}$.

Anos depois, em 1996, a Emenda Constitucional n. 10/1996 alterou a redação do Artigo 71 do ADCT para prorrogar a validade do FSE até junho de $1997^{211}$, além de incluir no referido dispositivo os parágrafos primeiro a terceiro, sendo que no $\$ 2^{\circ}$ criou o Fundo de Estabilização Fiscal, que apresentava os mesmos traços do FSE ${ }^{212}$. Nenhum dos dois fundos de fato compôs um fundo, mas foram alocados em distintas finalidades conforme a vontade do Governo Federal ${ }^{213}$.

No ano 2000, por meio da Emenda Constitucional n. 27/2000, o Legislativo Federal incluiu o artigo 76 ao ADCT ${ }^{214}$, prevendo a Desvinculação das Receitas da União entre 2000 a 2003, na razão de "vinte por cento da arrecadação de impostos e contribuições sociais da União, já instituídos ou que vierem a ser criados no referido período, seus adicionais e respectivos acréscimos legais" 215 .

Quando aproximado o fim da validade da DRU, nos termos da Emenda supramencionada que a instituiu, o Congresso se apressou em aprovar a Emenda Constitucional n. 42/2003, que previu a prorrogação da possibilidade de desvinculação até o ano de 2007, acrescentando nessa ocasião a desvinculação finalística das

210 ÁLVARES, Fernando. Brasil, economia e governo: desvinculação de receitas da União - DRU. Disponível em: <http://www.brasil-economia-governo.org.br/2011/12/05/o-que-e-e-para-que-serve-a-desvinculacao-de-rece itas-da-uniao-dru/>. Acesso em; 18 out. 2016.

211 BRASIL. Emenda Constitucional n. 10, de 4 de março de 1996. Altera os arts. 71 e 72 do Ato das Disposiçōes Constitucionais Transitórias, introduzidos pela Emenda Constitucional de Revisão n. 1, de 1994. Diário Oficial da União, Distrito Federal, 7 de março de 1996.

212 BARRETO, Paulo Ayres. Op. cit., p. 172.

213 DIAS, Fernando Álvares Correia; TAVARES, José Fernando Cosentino. Impacto da desvinculação de receitas da União no orçamento federal e em gastos sociais. Cadernos Aslegis, v. 3, n. 9, p. 50-77, 1999, p. 52.

214 BARRETO, Paulo Ayres. Op. cit., p. 172.

215 BRASIL. Emenda Constitucional n. 27, de 21 de Março de 2000. Acrescenta o art. 76 ao ato das Disposiçôes Constitucionais Transitórias, instituindo a desvinculação de arrecadação de impostos e contribuiçôes sociais da Uniāo. Diário Oficial da União. Distrito Federal, 22 de março de 2000. 
Contribuições de Intervenção no Domínio Econômico (CIDE) ${ }^{216}$. Posteriormente, mais duas prorrogações foram objeto das Emendas Constitucionais n. 56/2007, 68/2011 217 e, recentemente, a Emenda n. 93/2016, além de prorrogar a DRU até o ano de 2023, aumentou o percentual desvinculado de $20 \%$ (vinte por cento) para $30 \%$ (trinta por cento) ${ }^{218}$.

Em outros termos, até 2023 a DRU permitirá ao Governo Federal subtrair $30 \%$ (trinta por cento) do produto arrecadado com as contribuições sociais e de intervenção no domínio econômico e com as taxas, tanto as já existentes como as que vierem a ser criadas, para alocar à finalidade que bem entender, pouco importando, inclusive no caso das contribuições, a finalidade específica para as quais foram instituídas ${ }^{219}$.

Como não poderia deixar de ser, a matéria divide a opinião da doutrina. De início vale ressaltar a perspectiva de Barreto, segundo o qual a desvinculação da arrecadação das contribuições, ainda que parcial, promovida por Emendas Constitucionais, é inconstitucional por força do artigo $60, \$ 4^{\circ}$ da $\mathrm{CRFB} / 88$, eis que viola as garantias fundamentais do contribuinte $(i)$ de que o valor por ele recolhido a título de contribuição seja direcionado exclusivamente à finalidade que justifica a instituição do tributo e (ii) de que a respectiva contribuição não seja idêntica a outro tributo já discriminado na Constituição Federal ${ }^{220}$.

A desvinculação elimina a garantia individual de todos os contribuintes de somente recolher a contribuição aos cofres públicos se o valor por ele pago for fielmente utilizado na finalidade para a qual foi destinado, além do que, se o produto arrecadado é desvinculado, ainda que apenas parte dele, não será possível atingir a finalidade pretendida ${ }^{221}$.

216 DIAS, Fernando Álvares Correia. Desvinculação de receitas da União, gastos sociais e ajuste fiscal. 2008. Consultoria Legislativa do Senado Federal. Brasília, 2008. Disponível em:<http://www2. senado.leg.br/bdsf/bitstream/handle/id/94273/Texto\%20p\%20discuss\%C3\%A3o\%2039. pdf? sequence $=4>$. Acesso em: 30 nov. 2016 .

217 OLIVEIRA, Régis Fernandes de. Op. cit., p. 449.

218 Agência Senado. Nova Emenda Constitucional prorroga desvinculação de receitas da Uniāo. Disponível em: <http://www12.senado.leg.br/noticias/audios/2016/09/nova-emenda-constitucional-prorroga-desvinculacao-de-receitas-da-uniao>. Acesso em: 18 out. 2016.

219 Ibidem, passim.

220 BARRETO, Paulo Ayres. Op. cit., p. 175.

221 BARRETO, Paulo Ayres. Op. cit., p. 175. 
•• Tributação, direitos fundamentais e desenvolvimento

Ademais, sustenta o autor que a contribuição - ou parte a dela - desvinculada se torna, em verdade, pretenso imposto residual da União, previsto no artigo 154, I da CRFB/88, também maculado, contudo, de inconstitucionalidade, uma vez que tais impostos não podem ter base de cálculo e nem mesmo fato gerador de impostos já existentes ${ }^{222}$, o que não é respeitado com a DRU, que tira das contribuiçôes seu ponto divergente dos demais tributos fazendo com que ela possa se assemelhar a imposto em vigor.

Na mesma toada de Barreto, indo, porém, mais além, Scaff defende a existência do Princípio da Afetação das Contribuições, isto é, para ele o sujeito ativo da obrigação tributária tem o dever de aplicar o produto arrecadado em atuação que compreenda a finalidade justificadora da contribuição ${ }^{223}$, não havendo margem para que seja permitido ao Poder Público promover a desvinculação ${ }^{224}$.

$\mathrm{O}$ autor em comento salienta que a vinculação do produto da arrecadação das contribuições é uma questão de direitos humanos, trata-se de matéria que envolve direitos difusos e controle público e social do Estado ${ }^{225}$. Isto porque, ao subtrair receita da seguridade social, por exemplo, o constituinte derivado atinge verba que seria aplicada na saúde e na previdência, que expressam direitos sociais protegidos sob o manto das cláusulas pétreas por força do artigo $60, \$ 4^{\circ}, \mathrm{IV}$ da $\mathrm{CRFB} / 88^{226}$.

O enfoque da DRU em desvincular a arrecadação das contribuições sociais também leva estudiosos à interpretação de que a desvinculação vai de encontro ao artigo 167, XI da CRFB/88, que proíbe a utilização de recursos das contribuições previstas no artigo 195, I, a e II, para fim diverso do pagamento de benefícios previdenciários. Como consequência da desvinculação dessas contribuições, há violação clara e inegável ao direito social à previdência e assistência social, direitos fundamentais também protegidos pelo artigo $60, \$ 4^{\circ}$, IV ${ }^{227}$, que, afinal, são de aplicabilidade imediata capaz de configurar inadimplência do Estado perante to-

222 Ibidem, p. 176.

223 SCAFF, Fernando Facury. Direitos humanos e a desvinculação das receitas da União. Revista de Direito Administrativo, v. 236, p. 33-50, 2004, p. 33.

224 SCAFF, Fernando Facury. Op. cit., p. 34.

225 Ibidem, passim.

226 SCAFF, Fernando Facury. Op. cit., p. 47.

227 BRAGA, Karen Costa. A inconstitucionalidade da DRU sob a luz do inciso xi do artigo 167 da Constituição social e a falsa ideia do déficit previdenciário brasileiro. Revista Estudo \& Debate, v. 23, n. 1, 2016, p. 218. 
dos os que são lesados com a ausência de prestação - ou prestação precária - do serviço ou assistência ${ }^{228}$.

As contribuições de intervenção no domínio econômico, como instrumento do Estado de intervir na economia, logicamente tem o objetivo de efetivar os princípios da Ordem Econômica elencados no artigo $170^{229}$ da Constituição Federal ${ }^{230}$, seja através de uma atuação direta em que a própria incidência do tributo interfira ou indiretamente, custeando o atuação do Poder Público no domínio econômi$\mathrm{Co}^{231}$. De uma forma ou de outra, desvincular o produto arrecadado com as CIDE's acaba dando outra finalidade à verba que deveria ser usada para efetivar os princípios da Ordem Econômica.

A desvinculação decorrente de Emenda Constitucional também é criticada por Oliveira, que sustenta ser indevida a outorga ao Poder Executivo da possibilidade de alocar o produto da arrecadação de contribuições ao seu bel-prazer, sem se importar com o motivo que justificou a criação do tributo. $\mathrm{O}$ autor, reconhece que a Administração Pública não pode ser engessada a vinculações orçamentarias, pois precisa de alguma discricionariedade para alocar recursos nas áreas que julgar mais necessárias conforme a realidade ${ }^{232}$. Entretanto, a liberalidade do Poder Executivo não pode ser indiscriminada, sob pena de exonera-lo de cumprir as disposições orçamentárias ${ }^{233}$.

Também merece destaque a curiosa tese de que as Emendas Constitucionais que trouxeram as desvinculações criaram uma espécie tributária sui generis, parte

228 BREYNER, Frederico Menezes. Op. cit., p. 211.

229 Art. 170. A ordem econômica, fundada na valorização do trabalho humano e na livre iniciativa, tem por fim assegurar a todos existência digna, conforme os ditames da justiça social, observados os seguintes princípios: I - soberania nacional; II - propriedade privada; III - função social da propriedade; V - livre concorrência; V - defesa do consumidor; VI - defesa do meio ambiente, inclusive mediante tratamento diferenciado conforme o impacto ambiental dos produtos e serviços e de seus processos de elaboração e prestação; VII - redução das desigualdades regionais e sociais; VIII - busca do pleno emprego; IX - tratamento favorecido para as empresas de pequeno porte constituídas sob as leis brasileiras e que tenham sua sede e administração no País. Parágrafo único. É assegurado a todos o livre exercício de qualquer atividade econômica, independentemente de autorização de órgãos públicos, salvo nos casos previstos em lei.

230 BASSO, Maria Elisa. As contribuições de intervenção no dominio econômico: parâmetros para concretização de suas finalidades, p. 10.

231 Ibidem, p. 12.

232 OLIVEIRA, Régis Fernandes de. Op. cit., p. 449.

233 Ibidem, p. 450. 
•• Tributação, direitos fundamentais e desenvolvimento

imposto, parte contribuição, considerando que, inobstante o percentual desvinculado - atualmente 30\% (trinta por cento) -, 70\% (setenta por cento) ainda deve ser destinado aos fins que justificaram a sua criação ${ }^{234}$.

À essa tese de tributo híbrido se opõe com veemência parcela da doutrina, como é o caso de Barreto, que sustenta a impossibilidade de um mesmo tributo existir sob a forma de duas espécies tributárias que possuem fundamento constitucional distinto, cada qual com suas peculiaridades trazidas pela Carta Política ${ }^{235}$.

Essa corrente também é rejeitada pelo Supremo Tribunal Federal, que já firmou entendimento em sentido contrário, nos termos que seguem:

CONTRIBUIÇÃO SOCIAL. RECEITAS. DESVINCULAÇÃO. ARTIGO 76 DO ATO DAS DISPOSIÇŌES CONSTITUCIONAIS TRANSITÓRIAS EMENDAS CONSTITUCIONAIS N. 27, DE 2000 E N. 42, DE 2003. MODIFICAÇÃO NA APURAÇÃO DO FUNDO DE PARTICIPAÇÃO DOS MUNICÍPIOS. A desvinculação parcial da receita da União, constante do artigo 76 do Ato das Disposições Constitucionais Transitórias, não transforma as contribuiçôes sociais e de intervenção no domínio econômico em impostos, alterando a essência daquelas, ausente qualquer implicação quanto à apuração do Fundo de Participação dos Municípios. Precedente: Ação Direta de Inconstitucionalidade n. 2.925/DF, em que fui designado redator para o acórdão. MULTA AGRAVO ARTIGO 557, $\$ 2^{\circ}$, DO CÓDIGO DE PROCESSO CIVIL. Surgindo do exame do agravo o caráter manifestamente infundado, impõe-se a aplicação da multa prevista no $\$ 2^{\circ}$ do artigo 557 do Código de Processo Civil. ${ }^{236}$ (grifado)

Por outro lado, filiam-se a tese da hibridez Paulsen e Velloso, que apenas acrescentam uma peculiaridade: sustentam a manutenção da parte contribuição como espécie tributária autônoma que é, desde que a desvinculação não seja superior a 50\% (cinquenta por cento) do produto arrecadado. Caso contrário, predominando a desvinculação, não há como manter a natureza de contribuição sequer ao montante não desvinculado, hipótese em que será um imposto sui generis dada a vinculação de pequena parcela da arrecadação ${ }^{237}$.

Inobstante se posicionarem dessa forma, destacam categoricamente que se trata de verdadeira aberração jurídica que não pertence a uma espécie tributária e nem

234 PAULSEN, Leandro; VELLOSO, Andrei Pitten. Op. cit., p. 61.

235 BARRETO, Paulo Ayres. Op. cit., p. 176.

236 BRASIL. Supremo Tribunal Federal. RE 793564/PE. Relator: Min. Marco Aurélio. Data de Julgamento: 12.08.2014. Data de Publicação: 01.10.2014. Disponível em: <http://stf.jusbrasil.com.br/jurisprudencia/25286560/agreg-no-recurso-extraordinario-re-793564-pe-stf>. Acesso em: 23 out. 2016.

237 PAULSEN, Leandro; VELLOSO, Andrei Pitten. Op. cit., p. 63. 
a outra, criada com o objetivo de fraudar as regras constitucionais de repartição das receitas tributárias ${ }^{238}$.

Outro entendimento que busca dirimir a questão sustenta a cisão das contribuições existentes, que se manteriam intactas como tal no que tange à parcela da arrecadação regularmente destinada ao fim que lhe é próprio, mas se transmutariam em impostos na parte à qual se deu uma destinação oriunda da desvinculação ${ }^{239}$. Essa tese estabelece contribuições dúplices, que seriam, na verdade, impostos, já que a única diferença no caso seria a alíquota e nada mais ${ }^{240}$.

Interessante anotar que, apesar de considerarem inadmissível a tese de que as contribuições são cindidas com a DRU e se filiarem a corrente que defende um tributo sui generis como corolário da desvinculação, Paulsen e Velloso entendem não ser inconstitucional a desvinculação do produto da arrecadação das contribuições por meio de Emenda Constitucional2 ${ }^{241}$.

Expõem os aludidos autores, em linha totalmente oposta a Barreto, que carece de sentido a afirmativa de que a desvinculação em comento viola garantias individuais do contribuinte consubstanciadas na vedação à bitributação e na vedação à desfiguração das contribuições, argumentando para tanto que o Sistema Tributário trazido pela Constituição não é cláusula pétrea ${ }^{242}$.

Sob ótica diversa, Gabriel Demetrio Domingues suscita outra faceta problemática do tema ao sustentar que a desvinculação do produto da arrecadação das contribuições por Emenda Constitucional será inconstitucional sempre que abalar o Federalismo Fiscal e, ipso facto, a forma federativa de Estado, cláusula pétrea nos termos do artigo $60, \$ 4^{\circ}, I$ da CRFB/88. Ou seja, se, por força da desvinculação, a União agigantar ainda mais suas receitas e concorrer com os demais entes por tributar em campo que seria de competência desses ou, ainda, deturpar a natureza da contribuição desvinculada, de modo que ela se assemelhe a um imposto já existente cuja arrecadação seria repartida com os demais entes - que registra-se, é o que acontece com a DRU nos termos da EC n. 93/2016 -, a Emenda Constitucional deverá ser declarada inconstitucional em sede de controle de constitucionalidade

\footnotetext{
238 Ibidem, p. 61.

239 Ibidem, p. 62.

240 PAULSEN, Leandro; VELLOSO, Andrei Pitten. Op. cit., p. 63.

241 Ibidem, p. 66.

242 PAULSEN, Leandro; VELLOSO, Andrei Pitten. Op. cit., p. 66.
} 
•• Tributação, direitos fundamentais e desenvolvimento

exercido pelo Supremo Tribunal Federal, salvo se trouxer previsão de compensar o desequilíbrio por ela provocado ${ }^{243}$.

Com a nova redação dada ao artigo 76 do ADCT pela EC 93/2016, o $\$ 1^{\circ}$, que antes impedia que a DRU afetasse a repartição constitucional de receitas tributárias, foi revogado ${ }^{244}$, levando a crer que a vedação da redução da base de cálculo da aludida repartição poderá sim ser diminuída, inclusive quanto à diminuição do repasse para os Estados e Distrito Federal de parte do produto da arrecadação das CIDE's prevista no artigo 159, III da Constituição. Desse modo, sob a perspectiva de Domingues mencionada no parágrafo anterior, a EC 93/2016 está maculada de inconstitucionalidade, por desrespeito ao Federalismo Fiscal e consequente ofensa direta ao Princípio Federativo.

A respeito da análise da constitucionalidade da DRU, acredito ser de suma importância, também, a problemática suscitada por José Afonso da Silva, qual seja, a sua instituição e constante renovação por meio de Emenda ao Ato das Disposições Constitucionais Transitórias ${ }^{245}$, que, como a própria nomenclatura já sugere, tem o objetivo de cuidar de questóes específicas, excepcionais, por lapso temporal determinado ${ }^{246}$; as normas do ADCT nascem para, em algum momento, exaurirem sua eficácia ${ }^{247}$. Nesse sentido argumentou o Ministro Moreira Alves do Supremo Tribunal Federal, no julgamento da ADI 830-7. Destacou que, "sendo o ADCT integrado por normas transitórias às regras da parte permanente da Constituição, decorre da natureza mesma dessa transitoriedade a impossibilidade de vir a tornar-se perene por sucessivas alteraçôes de prazo" 248 .

243 DOMINGUES, Gabriel Demetrio. Op. cit., p. 77.

244 BRASIL. Emenda Constitucional n. 93, de 21 de Março de 2016. Altera o Ato das Disposições Constitucionais Transitórias para prorrogar a desvinculação de receitas da União e estabelecer a desvinculação de receitas dos Estados, Distrito Federal e Municípios. Diário Oficial da União. Distrito Federal, 9 de setembro de 2016.

245 SILVA, José Afonso da. Comentário contextual à Constituição. 8. ed. São Paulo: Malheiros, 2011, p. 961.

246 MENDES, Gilmar Ferreira; BRANCO, Paulo Gustavo. Curso de direito constitucional. 10. ed. São Paulo: Saraiva, 2015, p. 78-79.

247 BULOS, Uadi Lammêgo. Curso de direito constitucional. 9. ed. São Paulo: Saraiva, 2015, p. 1665.

248 BRASIL. Supremo Tribunal Federal. ADI 830/DF. Relator: Min. Moreira Alves. Data de Julgamento: 14.04.1993. Data de Publicação: 16.09.1994. Disponível em: <http://redir.stf. jus.br/paginadorpub/paginador.jsp?doc TP=AC\&docID=266554>. Acesso em: 26 out. 2016. 
A essência do ADCT é a transitoriedade. Destaca Uadi Lammêgo Bulos, que as normas transitórias visam garantir harmonia entre dois regimes constitucionais nos anos supervenientes ao advento de uma nova Constituição, impedindo que seja abalada a segurança jurídica ${ }^{249}$. O autor sustenta, também, que as normas do ADCT não podem ser objeto de Emendas reiteradamente para reavivar sua eficácia, sob pena de desvirtuar a natureza das disposições e agredir diretamente o corpo fixo da Constituição. Inclusive, se a eficácia da disposição transitória está próxima de seu fim, entende Bulos que ela não pode ser objeto de Emenda, pois isso caracterizaria igualmente as violações nos termos acima aludidos ${ }^{250}$.

A DRU, no entanto, contando com o interregno de vigência Fundo Social de Emergência, foi essencialmente instituída no ano de 1994, por meio da Emenda Constitucional de Revisão n. 1/1994, sob a forma do Fundo Social de Emergência e, ao invés de exaurir seus efeitos até o final do exercício financeiro de 1995, conforme previsto no texto da Emenda, vem sendo renovada consecutivamente e, por força da última renovação, vigorará até 2023.

Abstraindo-se todas as demais implicações da desvinculação em comento já ventiladas, pode até se pensar em considerar que ao tempo da edição da Emenda mencionada no parágrafo anterior havia razão para a inserção no Ordenamento de norma transitória para harmonizar o impacto do Plano Real, considerando-se, ainda, que a Constituição de 1988 era muito recente.

Entretanto, a partir do ano de 2000, com a Emenda Constitucional n. 27, até o ano de 2015 e, agora com a EC n. 93/2016, até o ano de 2023, todas alterando e estendendo a eficácia de normas que nasceram para ser transitórias, a DRU representa violação à natureza do ADCT, bem como inova - e, ipso facto, agride - matéria já prevista no corpo fixo da Constituição, qual seja, a vinculação finalística que caracteriza e autonomiza as contribuições.

Novamente abstraindo as outras questóes que abalam a constitucionalidade da DRU, deve-se ponderar que, ou há uma real necessidade transitória, que durará certo lapso temporal, ou há uma necessidade permanente. Uma alegada necessidade que se arrasta por mais de 20 (vinte) anos - e chegará quase aos 30 (trinta) com a nova prorrogação - não pode ser considerada transitória e, por conseguinte, não autoriza a utilização do ADCT.

249 Ibidem, p. 1667.

250 BULOS, Uadi Lammêgo. Op. cit., p. 1668. 
•• Tributação, direitos fundamentais e desenvolvimento

Apesar de toda a robusta manifestação contrária à DRU, há quem a defenda. No ano de 2011, a então Ministra de Estado do Planejamento Miriam Belchior declarou que desvincular as receitas da União é imprescindível para a promoção de políticas sociais e manutenção dos investimentos do Governo Federal, bem como sustentou que o orçamento Federal é fortemente engessado pela Constituiçãao e a desvinculação abre ao Executivo a possibilidade de alocar recursos em áreas estratégicas $^{251}$ - sem precisar, contudo, quais seriam essas áreas.

Mais recentemente, em 2015, o ex-Ministro de Estado do Planejamento Nelson Barbosa também defendeu a necessidade de prorrogação da DRU - o que, como já exposto, se concretizou com a aprovação da EC n. 93/2016 - para aliviar o engessamento orçamentário do Governo Federal trazido pela Constituição Federal e sugeriu que a desvinculação permite maior conforto à Administração para pagamento da dívida pública, por exemplo, e evita seu crescimento sem a necessidade de emissão de títulos da dívida pública, além de possibilitar aplicação de mais recursos em áreas como a previdência social ${ }^{252}$.

Nesse mesmo sentido, Fernando Álvares Correia Dias sustenta que, sem a DRU, não seria palpável ao Governo buscar superávit nas contas públicas ${ }^{253}$. Além disso, afirma que os serviços necessários à efetivação dos direitos sociais não deixaram de ser atendidos por causa da desvinculaçãao ${ }^{254}$, tanto que nem seria possível identificar precisamente qual setor a que seria destinada a arrecadação total das contribuiçôes foi mais impactado com a DRU ${ }^{255}$.

Uma crítica à essa perspectiva, além de todas as razões expostas no presente trabalho, como a violação de direitos sociais, situa-se, mormente, no fato de que o freio ao aumento da dívida pública, mesmo colocado como uma questão primordial de interesse público pela a gestão do Executivo em exercício, não justifica o desrespeito à supremacia da Constituição e dos direitos por ela preservados. Se há

251 BRASIL. Ministério do Planejamento, Orçamento e Gestão: Prorrogação da DRU é Fundamental para Políticas Sociais e de Investimento. Disponível em: <http://www.planejamento.gov. $\mathrm{br} /$ assuntos/orcamento/ noticias/prorrogacao-da-dru-e-fundamental-para-politicas $>$. Acesso em: 23 out. 2016.

252 BRASIL. Ministério do Planejamento, Orçamento e Gestão: Prorrogação da DRU. Disponível em: <http: //www.planejamento.gov.br/noticias/barbosa-defende-prorrogacao-da-dru-durante-audiencia-publica-na-camara-federal>. Acesso em: 23 out. 2016.

253 DIAS, Fernando Álvares Correia. Op. cit., p. 12.

${ }_{254}$ Ibidem, p. 13.

255 Ibidem, p. 17. 
previsão constitucional de vinculação das receitas, não cabe ao constituinte derivado mitigar essa determinação ${ }^{256}$ como se a Carta Política fosse uma norma inconveniente que perturba a administração do País ${ }^{257}$.

O Supremo Tribunal Federal não se sensibilizou com as teses que sustentam a inconstitucionalidade de Emenda à Constituição que promova a desvinculação do produto da arrecadação das contribuições. Analisando a DRU, a Corte por vezes declarou que a desvinculação não viola a Constituiçãa, como se observa abaixo:

AGRAVO REGIMENTAL EM RECURSO EXTRAORDINÁRIO. FUNDO SOCIAL DE EMERGÊNCIA. EMENDA CONSTITUCIONAL N. 10/1996. CONTRIBUIÇÃO SOCIAL SOBRE O LUCRO LÍQUIDO. VIOLAÇÃO AOS PRINCÍPIOS DA ANTERIORIDADE E DA IRRETROATIVIDADE. INOCORRÊNCIA. A destinação da arrecadação integra a norma tributária impositiva de uma contribuição, exceto se a desvinculação com relação ao fim originalmente previsto provém da própria Constituição Federal. A vinculação não assume, portanto, caráter de cláusula pétrea (RE 537610, Rel. Min. Cezar Peluso). $\mathrm{O}$ fato da arrecadaçáo da CSLL ter sido destinada ao custeio de um fundo, por força de determinação constitucional transitória, não fez com que o tributo fosse convertido em imposto. Reconhecido o dever de observância ao princípio da anterioridade mitigada, não há que se falar, na hipótese, de incidência sobre fatos geradores pretéritos. Agravo regimental a que se nega provimento. ${ }^{258}$ (grifado)

Neste caso, decidiu a Primeira Turma da Corte, por unanimidade, seguir o voto do Ministro-relator Luís Roberto Barroso, que rechaçou a inconstitucionalidade da DRU sob o argumento de que somente pode ser considerada inconstitucional a desvinculação que advém de normas infraconstitucionais. Quando o próprio texto constitucional excepciona a norma vinculatória, não há que se falar em inconstitucionalidade e nem mesmo pode-se afirmar que há alteração da natureza jurídica do tributo. Vejamos:

A parte agravante sustenta que: (i) a aplicação da receita tributária das contribuiçōes em finalidades diversas daquelas desejadas pela Constituição configura inconstitucionalidade; (ii) o agravamento da alíquota do tributo não pode atingir períodos de apuração já iniciados quando da entrada em vigor da norma majorante. (...) $\mathbf{O}$ agravo não pode ser provido, tendo em vista que a parte recorrente limita-se a reiterar

\footnotetext{
256 SCAFF, Fernando Facury. Op. cit., p. 48-49.

257 Ibidem, p. 50.

258 BRASIL. Supremo Tribunal Federal. RE 805.477/ES. Relator: Min. Roberto Barroso. Data de Julgamento: 07.10.2014. Data de Publicação: 30.10.2014. Disponível em: <http://stf.jusbrasil.com.br/jurisprudencia/25300805/agreg-no-recurso-extraordinario-re-805477-es-stf>. Acesso em: 23 out. 2016.
} 
•• Tributação, direitos fundamentais e desenvolvimento

argumentos já rechaçados, o que confirma a necessidade de manutenção da decisão. Tal como constatou a decisão agravada, se a legislação passa a atribuir destinaçáo diversa daquela que fornece suporte à instituição da contribuição, restará evidenciada a falta de correspondência entre a cobrança e a finalidade que a justifica, de modo que a referida tredestinação poderá invalidar a exação. A exceção a esta conclusão ocorre quando as modificações proveem da própria Constituição Federal. Emergindo diretamente da Carta, a alteração opera-se diretamente na regra de competência. Dessa forma, a descaracterização da vinculação não afeta a validade de uma contribuição e, por conseguinte, não interfere no seu regime jurídico. O fato de a arrecadação da CSLL estar voltada momentaneamente a fim diverso, por determinaçáo constitucional, não faz com que tal contribuiçáo seja trasladada ao regime dos impostos, o que faria com que a anterioridade aplicável ao caso fosse a anual (art. 150, III, b). A desvinculação da receita das contribuiçóes por força disposição constitucional já teve a sua possibilidade reconhecida. Confira-se, a propósito a ementa do RE 537.610, julgado sob a relatoria do Ministro Cezar Peluso. (...) As contribuiçôes destinadas ao Fundo instituído pelo constituinte reformador devem ser mantidas hígidas e inalteradas sob o enfoque tributário, de modo que o deslocamento dos recursos auferidos será, na hipótese, mera implicação financeira ${ }^{259}$ (grifado).

Outro julgado expressivo acerca do tema é o RE 566.007/RS, no âmago do qual o STF, além de reforçar a constitucionalidade do artigo 76 do ADCT, fixou a impossibilidade de restituição ao contribuinte dos valores pagos a título de contribuição que foram desvinculados por conta da DRU, mesmo na hipótese de ser o aludido dispositivo ofensivo à Constituição, já que a repetição de indébito só seria autorizada se a tributação em si fosse inconstitucional ou ilegal, o que não ocorre no caso examinado, posto que a verificação fática da hipótese de incidência e a norma instituidora estariam livre de vícios, conforme se observa na ementa abaixo:

DIREITOS CONSTITUCIONAL E TRIBUTÁRIO. REPERCUSSÃO GERAL. DESVINCULAÇÃO DE RECEITAS DA UNIÃO - DRU. ART. 76 DO ATO DAS DISPOSIÇÕES CONSTITUCIONAIS TRANSITÓRIAS. AUSÊNCIA DE CORRELAÇÃO ENTRE A ALEGADA INCONSTITUCIONALIDADE DA DRU E O DIREITO À DESONERAÇÃO TRIBUTÁRIA PROPORCIONAL À DESVINCULAÇÃO. ILEGITIMIDADE PROCESSUAL. AUSÊNCIA DE DIREITO LÍQUIDO E CERTO. RECURSO EXTRAORDINÁRIO AO QUAL SE NEGA PROVIMENTO. 1. A questão nuclear deste recurso extraordinário não é se o art. 76 do ADCT ofenderia norma permanente da Constituição da República, mas se, eventual inconstitucionalidade, conduziria a ter a Recorrente

259 BRASIL. Supremo Tribunal Federal. RE 805.477/ES. Relator: Min. Roberto Barroso. Data de Julgamento: 07.10.2014. Data de Publicação: 30.10.2014. Disponível em: <http://redir.stf. jus.br/paginadorpub/paginador.jsp?docTP=TP\&docID=7085838>. Acesso em: 23 out. 2016. 
direito à desoneração proporcional à desvinculação das contribuiçóes sociais recolhidas. 2. Não é possível concluir que, eventual inconstitucionalidade da desvinculação parcial da receita das contribuiçóes sociais, teria como consequência a devolução ao contribuinte do montante correspondente ao percentual desvinculado, pois a tributação não seria inconstitucional ou ilegal, única hipótese autorizadora da repetição do indébito tributário ou o reconhecimento de inexistência de relação jurídico-tributária. 3. Não tem legitimidade para a causa o contribuinte que pleiteia judicialmente a restituição ou o não recolhimento proporcional à desvinculação das receitas de contribuiçóes sociais instituída pelo art. 76 do ADCT, tanto em sua forma originária quanto na forma das alteraçôes promovidas pelas Emendas Constitucionais n. 27/2000, 42/2003, 56/2007, 59/2009 e 68/2011. Ausente direito líquido e certo para a impetração de mandados de segurança. 4. Negado provimento ao recurso extraordinário. ${ }^{260}$ (grifado)

Este julgamento ocorrido no ano de 2014 traz, também, peculiaridade interessante. Em seu voto, o Ministro Luiz Fux destaca que a DRU, por força do disposto no $\$ 1^{\circ}$ do artigo 76 , não provoca alteração na base de cálculo das transferências feitas pela União aos Estados, Distrito Federal e Municípios, previstas no $\$ 5^{\circ}$ do artigo 153 , no inciso I do artigo 157, nos incisos I e II do artigo 158 e nas alíneas "a", "b" e "d" do inciso I e no inciso II do artigo 159 da Constituição Federal, nem na base de cálculo das destinações a que se refere a alínea "c" do inciso I do art. 159 da Constituição Federal. Assim sendo, não haveria violação a cláusula pétrea, já que, negada a violação a direitos e garantias fundamentais, também não há violação à forma federativa de Estado. Vejamos trecho do voto do i. Ministro:

Senhor Presidente, eu também acompanho a eminente Ministra-Relatora, mas não sem antes consignar que o eminente Advogado especialista do tema trouxe algumas questôes que merecem ser sinteticamente rechaçadas. É que, em um primeiro momento, aduziu que essa desvinculação retira uma parte da verba da seguridade social, o que geraria, de alguma maneira, uma ruptura do pacto federativo, até porque também influenciaria naquela repartição das receitas da União para os Estados. Aí eu verifico aqui, Senhor Presidente, que o próprio art. 76 - e até comentava com o Ministro Teori Zavascki, que me revelou a sua inteligência sobre o dispositivo -, apesar da desvinculação, não há nenhuma alteração na base de cálculo das transferências, então, o disposto no artigo não reduzirá base de cálculo das transferências aos Estados.

260 BRASIL. Supremo Tribunal Federal. RE 566.007/RS. Relator: Min. Cármen Lúcia. Data de Julgamento: 02/04/2014. Data de Publicação: 24.04.2014. Disponível em: <http://redir.stf. jus.br/paginadorpub /paginador.jsp?docTP=TP\&docID=7719221>. Acesso em: 23 out. 2016. 
•• Tributação, direitos fundamentais e desenvolvimento

Assim, não há efetivamente nenhuma violação ao pacto federativo e, a fortiori, não há também nenhuma violação de cláusula pétrea. ${ }^{261}$

Das palavras do i. ministro, pode-se extrair que, caso a Emenda Constitucional em análise no julgado, qual seja, EC n. 68/2011, previsse a redução da base de cálculo das transferências que são obrigatórias a União, muito possivelmente o voto seria no sentido oposto, para reconhecer o vício de inconstitucionalidade por conta da violação ao Pacto Federativo.

Ocorre que a recente Emenda Constitucional n. 93/2016, que prorrogou a DRU até o ano de 2023, revogou o aludido dispositivo que vedava a redução nas bases de cálculo das transferências da União aos demais Entes Federativos. Logo, por mais que o foco do presente trabalho não seja os efeitos da DRU sobre os impostos, mas apenas sobre as contribuições e, considerando que poderá ser diminuído até mesmo o repasse para os Estados e Distrito Federal de parte do produto da arrecadação das CIDE's prevista no artigo 159, III da Constituição, não há como passar pelo voto do Ministro Fux sem se perguntar se, a partir de agora, permanecerá o entendimento que dele se extrai, qual seja, o de que a permissão para alterar a base de cálculo das transferências em comento seria capaz de eivar a DRU de inconstitucionalidade. Resta-nos aguardar o pronunciamento da Corte sobre a questão em eventual demanda.

Por fim, ouso me posicionar pela inconstitucionalidade da DRU por estar convencido de que (i) as Emendas Constitucionais que vêm a prorrogando por tanto tempo afrontam a finalidade precípua de transitoriedade das normas do ADCT, pois, ainda que se considere que não havia qualquer vício ao tempo de sua instituição, a desvinculação perdeu seu caráter temporário e foi adotada como medida comum nos Governos para sanar deficiências na administração dos recursos públicos.

Ainda, (ii) direitos fundamentais - sobretudo direitos sociais, nos termos suscitados no presente trabalho - são violados por conta das desvinculações das contribuições sociais e a efetivação dos princípios norteadores da Ordem Econômica é prejudicada com a desvinculação das contribuiçôes de intervenção do domínio econômico.

261 BRASIL. Supremo Tribunal Federal. RE 566.007/RS. Relator: Min. Cármen Lúcia. Data de Julgamento: 02/04/2014. Data de Publicação: 24.04.2014. Disponível em: <http://redir.stf. jus.br/paginadorpub /paginador.jsp?docTP=TP\&docID=7719221>. Acesso em: 23 out. 2016. 
A inconstitucionalidade se revela, também, pela (iii) desvinculação finalística, ainda que parcial, que subtrai das contribuições o traço que lhes é peculiar em relação aos demais tributos. Simplesmente não há possibilidade lógica de que uma contribuição cuja arrecadação não é aplicada no fim que lhe justifica continue sendo contribuição e não faça da Constituição letra morta quanto à finalidade específica que dispõe para o tributo. Para criar tributos desvinculados, a Carta Política já trouxe os impostos residuais de competência da União, sendo completamente incongruente - por conseguinte, inconstitucional - a desvinculação das contribuiçõoes.

Além disso, ao desvincular tributo com finalidade certa e determinada pela Constituição (iv) a DRU representa verdadeiro óbice à tributação transparente e honesta a que tem direito os contribuintes, em dissonância com o tão caro Princípio Democrático que permite ao povo eleger seus representantes para que governem com transparência e eficiência buscando satisfazer os direitos básicos e as reais prioridades da sociedade.

\section{A CRISE NA PREVIDÊNCIA SOCIAL COMO COROLÁRIO DA DRU. SOLUÇÕES POSSÍVEIS PARA A DESVINCULAÇÃO FINALÍSTICA DAS CONTRIBUIÇÕES.}

Derradeiramente, traz-se à baila um assunto que tem ligação direta com a desvinculação de receitas das contribuiçôes no plano constitucional: a questionável crise na previdência social. Em seguida, serão ventiladas sugestôes para resolver a problemática lançada no trabalho.

\subsection{A crise na Previdência Social}

Como é de sabença comezinha, nossa atual Constituição tem marcante caráter garantista e adotou uma política bastante protetiva quanto à seguridade social, que garante à sociedade a prestação de serviços de saúde, previdência e assistência social pelo Estado de modo, no mínimo, satisfatório, reservando verba orçamentária para $\tan t^{262}$.

As contribuiç̧óes sociais, previstas nos artigos 149 e 195 da CRFB/88, têm justamente o objetivo de custear a implementação desses serviços tão importantes

62 BRAGA, Karen Costa. Op. cit., p. 218. 
•• Tributação, direitos fundamentais e desenvolvimento

para a sociedade, de forma que não deixem de ser prestados eficientemente em hipótese alguma ${ }^{263}$. Tanto é esse o propósito, que a Constituição traz expressa vedação à destinação do produto da arrecadação das contribuiçôes do empregador e do empregado, previstas no artigo 195, I e II da CRFB/88, respectivamente, à finalidade diversa do pagamento de benefícios previdenciários, nos termos do artigo 167, IX da CRFB/88, significativo de uma proibição que, nas palavras de José Afonso da Silva, "é inerente à natureza das contribuiçōes sociais"264.

Tal conclusão é alcançável se refletirmos, ainda que brevemente, sobre o fato de que, se a essencialidade de manter intacta a seguridade não prescindisse de qualquer situação, não teria o constituinte sido tão específico, por exemplo, em preservar verba para o pagamento de benefícios previdenciários - como mencionado no parágrafo anterior - que possuem inegável natureza assistencial. Ainda, se a seguridade não fosse de importância ímpar, não teria o constituinte, também, elencado a seguridade como direito social no artigo $6^{\circ} \mathrm{da} C R F B / 88$, que traduz verdadeira garantia fundamental a todas as pessoas.

Entretanto, muito tem-se ouvido hodiernamente sobre a crise que atinge a previdência social, com previsão de déficit cada vez maior nos próximos anos ${ }^{265}$. A contrario sensu, não se verifica uma queda na arrecadação das contribuições sociais capaz de justificar a falta de dinheiro para bancar a seguridade ${ }^{266}$. Mesmo com constante superávit, a seguridade está sempre em meio a problemas financeiros e enfrenta grande dificuldade para sobreviver de forma eficiente e satisfatória para os segurados ${ }^{267}$. Até mesmo o Sistema Único de Saúde poderia ser mais fortalecido e eficaz se não houvesse desvinculação de verbas da seguridade ${ }^{268}$.

A DRU, consoante já exposto no presente trabalho, abocanha fatia generosa da arrecadação que acaba fazendo toda a diferença para o suporte da previdência.

63 BREYNER, Frederico Menezes. Op. cit., p. 304.

264 SILVA, José Afonso da. Op. cit., p. 713.

265 SALOMÃO, Alexandre. O Estadão: recessão antecipa a crise na previdência. Disponível em: <http://economia.estadao.com.br/noticias/geral,recessao-antecipa-a-crise-na-previdencia,1769666>. Acesso em: 25 out. 2016.

266 BRAGA, Karen Costa. Op. cit., p. 224.

267 MARQUES, Rosa Maria M.; MENDES, Áquilas. Os dilemas do financiamento do SUS no interior da seguridade social. Economia e Sociedade, v. 14, n. 1, p. 159-175, 2016, p. 162.

268 Ibidem, p. 165. 
Para melhor elucidar e aquecer o debate, cumpre transcrever texto de Karen Braga Costa, que aduz a questão com hialina clareza:

Segundo um estudo divulgado pela Associação Nacional dos Auditores Fiscais da Receita Federal do Brasil (Anfip), apenas no ano de 2014 a receita da Seguridade Social totalizou R \$ 686,1 bilhōes, o que se pode considerar uma boa arrecadação, pois superou em R \$35,1 bilhões a arrecadação de 2013. Desse valor, foi desvinculado do Orçamento da Seguridade Social o montante de R \$ 63,161 bilhôes a título de DRU. O total de despesas da Seguridade Social somou R \$ 632,2 bilhôes. Incluem-se neste conceito os pagamentos efetuados pelo Regime Geral de Previdência Social RGPS que, no ano paradigma de 2014, somaram R \$394,2 bilhôes. Os gastos com a Saúde totalizaram R $\$ 94,2$ bilhões de reais e, por fim, o pagamento dos benefícios $\mathrm{da}$ Assistência Social (LOAS) atingiu R \$ 37,6 bilhões. Deve ser acrescentado nessas despesas o desembolso de $\mathrm{R} \$ 51,8$ bilhões para o pagamento de dois significativos programas sociais: o seguro-desemprego e o abono salarial pago pelo Fundo de Amparo ao Trabalhador (FAT). Para o Bolsa Família foram destinados R $\$ 26.162$ bilhões e as demais despesas, que totalizaram $\mathrm{R} \$ 121.883$ bilhões, foram destinadas para o custeio de funcionários ativos do Ministério da Saúde, do Ministério do Desenvolvimento Social e Ministério da Previdência Social, bem como despesas relativas ao custeio e investimento nos programas sociais. Portanto, o total de despesas somou R \$ 632,199 bilhões, deixando um saldo superavitário de $\mathrm{R}$ \$ 53,9 bilhōes de reais "em caixa" para a Seguridade Social, segundo o Estudo da Anfip divulgado em 2015. Apenas a título de comparação: os valores desvinculados pela DRU seriam capazes de pagar todos os benefícios previdenciários concedidos durante o ano de 2014 no Estado de Minas Gerais, que totalizaram $\mathrm{R} \$ 5.048 .983 .841,00$; do Estado do Rio de Janeiro, que totalizaram R \$ 39.251.904.280,00; do Distrito Federal em que R 3.833.609.110,00 em benefícios foram concedidos, e ainda restaria saldo remanescente, segundo Anuário publicado pelo Ministério da Previdência Social em 2015. ${ }^{269}$

Como é possível acatar a suposta crise na previdência diante do exposto acima? É forçoso afirmar que a má gestão do Governo Federal ou, ainda, o desinteresse em manter fortalecida a previdência social conjugado com prioridades diversas das que representam a essência constitucional, estão sendo mascarados por um déficit que não existe ${ }^{270}$.

É pertinente registrar a fragilidade do argumento de que a Constituição prevê um orçamento público com pouca margem para o administrador, porque isso não justifica a desvinculação de receitas das contribuições, a fortiori das contribuições sociais, diante dos direitos essenciais à dignidade humana que elas visam proteger ${ }^{271}$.

\footnotetext{
269 BRAGA, Karen Costa. Op. cit., p. 224.

270 BRAGA, Karen Costa. Op. cit., p. 225.

271 Ibidem, p. 226.
} 
•• Tributação, direitos fundamentais e desenvolvimento

O rombo existe nas contas do Governo, mas não na Previdência. É o que diz a Associação Nacional dos Auditores Fiscais da Receita Federal (ANFIP), segundo a qual o déficit na previdência é uma falácia criada pelo Executivo, que exclui das receitas da seguridade a arrecadação angariada com a Contribuição para o Financiamento da Seguridade Social (Cofins) e com a Contribuição Social sobre o Lucro Líquido (CSLL), e outras mais. O dinheiro que não é aplicado na seguridade é, através da DRU, desvinculado para ser aplicado a finalidades estranhas, mormente para amortização da dívida pública ${ }^{272}$.

Percebe-se que, na verdade, se falta dinheiro para a previdência, o principal motivo é a desvinculação de receitas proporcionadas pela DRU, já que parte da arrecadação das contribuições sociais sequer entra no orçamento da seguridade social. Só há crise na previdência por causa da DRU. Se ela não existisse e o Administrador Público alocasse os recursos em comento no fim que lhe é próprio, não só não haveria crise, como a previdência - e a seguridade de modo geral - teriam reserva para os momentos de queda na arrecadação e os serviços não deixariam de ser prestados de modo eficiente.

Há, contudo, estudiosos do tema que entendem haver sim uma crise na previdência e atribuem essa crise a fatores históricos. É o caso de Fábio Giambiagi e Ana Cláudia Além, que destacam que a Constituição Federal de 1988 é primorosa em elencar direitos mas é deficiente em dispor deveres e orçamento para consubstanciar os direitos previstos ${ }^{273}$. Não me parece, contudo, ser exigível do Constituinte postura menos garantista na época, já que o país estava saindo de um período de duas décadas sob regime ditatorial com corriqueiras violaçôes de direitos fundamentais.

Os autores sustentam que o regime previdenciário calcado no sistema solidário, que funciona com o custeio dos aposentados pelos ativos conjugado com a precoce faixa etária apta para se aposentar (mulheres de 55-60 e homens de 60-65), acaba gerando um número grandioso de beneficiários e criando um sistema maior de despesas do que de receitas ${ }^{274}$.

272 LEMOS, Anfredo Miranda. Como o governo fabrica o falso déficit da previdência? ANFIP. Disponível em: <http://www.anfip.org.br/informacoes/artigos/Como-o-governo-fabrica-o-falso-deficit-ou-falso-rombo-da-Previdencia-Alfredo-Miranda-de-Lemos_03-10-2016>. Acesso em: 1 nov. 2016.

273 GIAMBIAGI, Fábio; ALÉM, Ana Cláudia. Finanças públicas: teoria e prática no Brasil. 4. ed. rev. e atual. Rio de Janeiro: Elsevier, 2011, p. 285.

274 GIAMBIAGI, Fábio; ALÉM, Ana Cláudia. Op. cit., p. 284-285. 
Esse cenário, segundo os autores em comento, engrandece os gastos com previdência e diminui o numerário destinado, por exemplo, à saúde, justificando, portanto, a adoção de medidas como a criação da Contribuição Provisória sobre Movimentações Financeiras, instituída no ano de 1997 e cobrada até o ano de 2007 sob o argumento de arrecadar dinheiro para aplicação no aludido setor ${ }^{275}$.

$\mathrm{O}$ argumento, contudo, enfraquece, quando nos deparamos com a constatação de que menos da metade dos mais de R\$ 223.000.000.000,00 (duzentos e vinte e três bilhões de reais) arrecadados com a CPMF foi de fato destinado à saúde, mas sim a outros fins definidos pela livre vontade do Governo Federal, conforme dados apurados pela Receita Federal e divulgados pelo Senado Federal ${ }^{276}$.

Mais frágil ainda se revela o argumento, tendo em vista que, como dito exaustivamente, as contribuições destinadas ao custeio da previdência - e também da seguridade como um todo - são capazes de arcar com os custos que ela ocasiona hoje, bastando para tanto que o produto de sua arrecadação não seja desvinculado.

Enfim, não me parece aceitável que setor tão importante para a concretização de direitos sociais tenha seu orçamento enfraquecido por conta da desvinculação de receitas que lhe são próprias por garantia constitucional. A propagação da notícia de que a previdência está em crise soa como uma tentativa de construir um ambiente propício para que o Governo Federal sofra menos pressão da sociedade em futuras modificações na legislação que toca em direitos sociais, sobretudo questôes previdenciárias.

Por esse e outros inúmeros motivos suscitados no presente trabalho que fazem da DRU, ou outro modelo semelhante de desvinculação das contribuições que venham a ser estabelecidas, um problema, cumpre apresentar a seguir algumas possíveis soluções para a questão.

\subsection{Possíveis soluções para a desvinculação finalística das contribuiç̧ões}

A desvinculação do produto arrecadado com as contribuições pode ser combatida através da atuação do Poder Judiciário no exercício do controle repressivo de constitucionalidade das normas, bem como por meio da atuação do Poder

Ibidem, p. 285.

276 BRASIL. Agência Senado: CPMF. Disponível em: <http://www12.senado.leg.br/noticias/ entenda-o-assun to/cpmf>. Acesso em: 2 nov. 2016. 
•• Tributação, direitos fundamentais e desenvolvimento

Legislativo no exercício de sua função legiferante, se efetivamente necessário, consoante exposto abaixo.

\subsubsection{Atuação do Poder Judiciário}

No presente trabalho, a desvinculação finalística das contribuições foi analisada nas hipóteses em que decorre de lei, inclusive de lei orçamentária, bem como nos casos em que deriva de norma inserida no Texto Constitucional.

Em ambas as hipóteses, como forma de impedir que a nova norma jurídica inconstitucional permaneça em vigor no Ordenamento Jurídico, cabe aos legitimados ativos para propositura das ações do controle concentrado de constitucionalidade, elencados no artigo 103, I a IX da CRFB, sobretudo os legitimados universais, quais sejam, o Presidente da República, as Mesas do Senado e da Câmera dos Deputados, o Procurador-Geral da República, o Conselho Federal da Ordem dos Advogados do Brasil ou, ainda, qualquer partido político com representação no Congresso Nacional ${ }^{277}$, exercer a faculdade que lhes é atribuída e ajuizar uma Ação Direta de Inconstitucionalidade para impugnar a norma viciada.

Como é de amplo conhecimento, a Ação Direta de Inconstitucionalidade tem por objeto a análise da validade de lei ou ato normativo federal ou estadual em face da Constituição da República ${ }^{278}$. Isto é, todas as espécies normativas de origem estadual ou federal que extraiam seu fundamento da validade diretamente da Constituição, podem ser objeto de controle, inclusive Emendas constitucionais ${ }^{279} \mathrm{e}$ leis orçamentárias ${ }^{280}$.

Com isso, caso o legislador pretenda editar lei que institua a destinação finalística das contribuições, esse ato normativo, após entrar em vigor, deve ser objeto do controle repressivo de constitucionalidade em ADI própria para tanto, proposta por ao menos um dos legitimados universais supramencionados. De igual modo devem estes proceder quando o constituinte derivado tencionar inserir no texto constitucional norma com a mesma finalidade através de Emenda à Constituição.

BARROSO, Luís Roberto. O controle de constitucionalidade no direito brasileiro. 6. ed. São Paulo: Saraiva, 2012, p. 188.

278 BARROSO, Luís Roberto. Op. cit., p. 198.

279 Ibidem, p. 200.

280 Ibidem, p. 199. 
Uma vez ajuizada a ADI, se espera que o STF, exercendo sua função precípua de guardar a Constituição da República, decida pela procedência da ação declarando inconstitucional a norma impugnada, que deixará, então, de ser aplicada.

\subsubsection{Atuação do Poder Legislativo}

No Ordenamento Brasileiro, o Poder Judiciário, via de regra, exerce o controle repressivo de constitucionalidade das normas e, desse modo, obviamente, somente impede a aplicação de norma inconstitucional depois que a mesma entra em vigor, conforme exposto acima.

Assim sendo, para que uma norma que preveja a desvinculação finalística das contribuições sequer seja discutida, é preciso que o Poder Legislativo se policie e não inaugure processo legislativo com finalidade de aprová-la.

No entanto, como mostrado no presente trabalho, a principal justificativa para que a desvinculação do produto arrecadado com as contribuições aconteça é a crise nas finanças públicas aliada a diversas vinculaçóes de receita previstas na Constituição da República, que representariam um engessamento do Poder Executivo, dificultando a superação do déficit orçamentário.

A análise profunda da real necessidade do Executivo de dispor livremente da verba desvinculada das contribuiçôes não está inclusa no objetivo central do presente trabalho, até mesmo por fugir de um estudo estritamente jurídico. Mas, abstraindo-se a qualidade dos planos e pretensões do Governo Federal, caso a União precise de fato do dinheiro desvinculado da arrecadação das contribuições para alocá-lo em outros setores, outros meios de obtenção de receitas devem ser utilizados para que seja afastada a medida inconstitucional.

Nesse diapasão, serão ventiladas duas possíveis soluções de lege ferenda para substituir a desvinculação finalística das contribuições. São elas (i) uma exploração maior da seletividade do Imposto sobre Produtos Industrializados e (ii) o exercício da competência da União para instituir impostos residuais.

A Constituição da República atribui, por força de seu artigo 153, IV, à União, a competência para instituir o IPI que incide, em linhas gerais, sobre operações com produtos industrializados, isto é, recai sobre as operações em que participa o industrial que promoveu a industrialização e não sobre a operação entre comerciante e consumidor ${ }^{281}$. Um dos principais critérios constitucionais para a instituição do

281 PAULSEN, Leandro; MELO, José Eduardo Soares de. Impostos Federais, Estaduais e Municipais. 7. ed. rev e atual. Porto Alegre: Livraria do Advogado, 2012, p. 92. 
IPI é a seletividade, que lhe é concedida pelo $₫ 3^{\circ}$ do artigo 153 da CRFB/88. Isto significa que a tributação deve ser diferenciada em função da qualidade do produto objeto da operação tributada ${ }^{282}$, em outras palavras, conforme seja esse produto mais ou menos essencial para a sociedade, a alíquota do imposto será fixada em percentual maior ou menor ${ }^{283}$.

Com isso, se constatada uma crise nas contas do Governo Federal, este pode, utilizando-se da norma de competência supracitada e da autorização para alteração de algumas alíquotas, respeitando-se a anterioridade nonagesimal, com fulcro no artigo $153, \$ 1^{\circ} \mathrm{c} / \mathrm{c}$ artigo $150, \$ 1^{\circ}$ da CRFB, majorar a alíquota do IPI quanto a produtos não essenciais, como é o caso do cigarro e produtos relacionados ao fumo, de bebidas alcoólicas, produtos de beleza puramente estéticos, a exemplo de cremes para rejuvenescimento da pele, e joias.

Não há dúvidas de que a União já explora a seletividade do IPI sobre esses produtos, mas não parece haver prejuízo em aumentar ainda mais as respectivas alíquotas para aumentar a arrecadação em momentos de crise, posto que tratam-se de produtos totalmente dispensáveis que, via de regra, são consumidos pelas classes mais altas da sociedade que não deixarão de consumi-los pelo aumento do preço - no caso do cigarro e das bebidas alcoólicas há ainda os malefícios que podem causar à saúde.

Além da seletividade do IPI, para aumentar a arrecadação a União pode também utilizar-se da competência para instituição de impostos que ainda não existem e não estão no âmbito de competência de outro Ente da Federação, respeitadas a não cumulatividade, bem como fato gerador e base de cálculo de imposto já previsto no Texto Constitucional, nos termos do artigo 154, I da CRFB/88.

Uma possibilidade, é instituir imposto sobre a propriedade de veículos aquáticos, a fim de que os proprietários de iates, lanchas e outras embarcações contribuam mais para os cofres públicos. Além disso, também é possível instituir imposto sobre a propriedade de veículos aeronáuticos, para que os proprietários de todos os tipos de aeronaves também ajudem a alavancar a arrecadação tributária da União.

Cumpre destacar que os aludidos impostos representariam aumento da arrecadação com observância da capacidade contributiva, uma vez que somente são

282 Ibidem, p. 98.

283 Ibidem, p. 99. 
proprietários de veículos aquáticos ou aeronáuticos pessoas pertencentes às classes mais altas da sociedade, que não sofrerão impacto financeiro expressivo com a nova tributação.

Essas medidas, aliadas a uma administração competente, certamente ajudariam a União a diminuir o déficit nas contas e, talvez, até mesmo alcançar superávit sem que, para tanto, seja admitida a desvinculação finalística das contribuições.

\section{CONCLUSÃO}

De todo o refletido no presente trabalho, diversas premissas são alcançadas e todas convergem para a conclusão de que é insustentável a constitucionalidade da desvinculação finalística das contribuições, seja no plano infraconstitucional, seja no plano constitucional com a manifestação do Poder Constituinte Derivado.

A certeira autonomia das contribuições, inegável por conta de uma interpretação sistemática da Constituição Federal que expressa a teoria quinquipartite, corroborada pela característica própria de vinculação do produto arrecadado, estabelece uma inquebrável relação de causa e efeito entre o fim ao qual deve ser aplicada a arrecadação e a permissividade para sua instituição. Se subtraída das contribuições sua vinculação finalística, impossível é afirmar que o tributo se mantém intacto, já que poderá estar-se diante de um caso em que nada haverá de diferente entre a contribuição em questão e imposto já existente.

Em outros termos, pode-se dizer que, mesmo que as contribuições tenham regra-matriz de incidência com a mesma estrutura dos demais tributos e que a vinculação finalística não seja elemento componente da regra-matriz das contribuições, a lei que institui contribuição sem respeitar finalidade estabelecida pela Constituição Federal, está incontestavelmente eivada de inconstitucionalidade, assim como norma posterior que seja editada unicamente para desvincular o produto arrecadado com contribuição já existente, cuja lei instituidora foi editada em consonância com o Texto Constitucional.

Nesse diapasão, diferente não é o tratamento dispendido às leis orçamentárias que, inobstante serem lei em sentido formal e representarem a vontade do Governo na alocação de recursos, também não têm permissão para prever a tredestinação das contribuiçóes e, ipso facto, será inconstitucional se o fizer.

Nem mesmo o constituinte derivado tem a liberalidade de editar Emenda Constitucional com o objetivo de inserir no Texto Constitucional norma para 
•• Tributação, direitos fundamentais e desenvolvimento

autorizar a desvinculação finalística das contribuições. A DRU, manifestação autêntica da tredestinação introduzida por Norma Constitucional, ao prever a desvinculação do produto de Contribuições Sociais e de Intervenção do Domínio Econômico, mostra essa flagrante invalidade por violar direitos fundamentais, mormente os direitos sociais - cláusulas pétreas conforme artigo $60, \$ 4^{\circ}$, IV da CRFB/88 - e prejudicar a efetivação dos princípios norteadores da Ordem Econômica.

A Seguridade Social - e principalmente a Previdência Social - vem sofrendo com a falta de recursos quando, em contrapartida, a arrecadação das Contribuições Sociais cresce. A desvinculação ocasionada pela DRU, ao mesmo tempo em que entrega nas mãos do Administrador Público poder para alocar como bem entender recursos com finalidade certa, provoca na Seguridade e, repita-se, principalmente na Previdência, crise que não existe.

A tredestinação das contribuiçõoes prejudica, ainda, a consecução de uma tributação transparente aos contribuintes, em desacordo com o Estado Democrático de Direito, no qual o povo elege seus representantes com o objetivo de que exerçam uma gestão transparente e eficiente, procurando satisfazer os direitos mínimos e as reais necessidades da sociedade.

Há ainda o fato de que as Emendas Constitucionais que têm por objeto a prorrogação da DRU vão de encontro ao caráter essencialmente transitório das normas do ADCT, afinal, nada há de transitório em uma norma que, com o advento da EC 93/2016, completará quase 30 (trinta) anos de vigência contadas as sucessivas renovações.

Se a Constituição da República fosse favorável à desvinculação da arrecadação das contribuições em alguma hipótese ou entendesse que tal vinculação é prescindível para garantir a atuação do Poder Público nos setores atingidos, não teria dado à União a faculdade de criar tributos com arrecadação afetada em concomitância com a competência para instituição de impostos residuais.

É lamentável que todas essas razões ainda não tenham sido acolhidas pelo Supremo Tribunal Federal, que insiste em negar a inconstitucionalidade da DRU. A substituição da receita desvinculada com a DRU e aplicada em setores diversos pode ser compensada, se realmente necessária, com o exercício da competência residual da União para instituir impostos prevista no artigo 154, I da CRFB/88. Não há outra saída, contudo, para deixar de ser aplicada norma inconstitucional em vigor, sem revogá-la, que não seja a declaração de sua inconstitucionalidade pelo 
STF, razão pela qual se espera que a questão ainda seja levada a julgamento muitas vezes para que os Ministros sejam convencidos a mudar o entendimento da Corte.

\section{REFERÊNCIAS}

BALEEIRO, Aliomar. Uma introdução à ciência das finanças. 15. ed. Rio de Janeiro: Forense, 1997.

BARRETO, Paulo Ayres. Contribuiçôes: regime jurídico, destinação e controle. São Paulo: Noeses, 2006.

BARROSO, Luís Roberto. O controle de constitucionalidade no direito brasileiro. 6. ed. rev. e atual. São Paulo: Saraiva, 2012.

BASSO, Maria Elisa. As contribuiçôes de intervenção no domínio econômico: parâmetros para concretização de suas finalidades. 2007. 34f. Artigo extraído do Trabalho de Conclusão de Curso apresentado como requisito parcial à obtenção do grau de Bacharel em Direito - Faculdade de Direito, Pontifícia Universidade Católica do Rio Grande do Sul, Rio Grande do Sul, 2007.

BRAGA, Karen Costa. A inconstitucionalidade da DRU sob a luz do inciso XI do artigo 167 da Constituição Social e a falsa ideia do déficit previdenciário brasileiro. Revista Estudo \&. Debate, v. 23, n. 1, 2016.

BRASIL. Barbosa defende prorrogação da DRU durante audiência pública na Câmara Federal. Disponível em: <http://www.planejamento.gov.br/noticias/barbosa-defende-prorrogacaoda-dru-durante-audiencia-publica-na-camara-federal>. Acesso em: 23 out. 2016.

BRASIL. A Constituição e o Supremo. Disponível em: <http://www.stf.jus.br/portal/ constituicao/artigoBd.asp?item=1634>. Acesso em: 26 nov. 2016.

BRASIL. Como o governo fabrica o falso déficit (ou falso rombo) da Previdência? Disponível em: <http://www.anfip.org.br/informacoes/artigos/Como-o-governo-fabrica-o-falsodeficit-ou-falso-rombo-da-Previdencia-Alfredo-Miranda-de-Lemos_03-10-2016>. Acesso em: 1 nov. 2016.

BRASIL. Constituição da República Federativa do Brasil, de 5 de outubro de 1988. Diário Oficial da União. Distrito Federal, 5 de outubro de 1988.

BRASIL. CPMF. Disponível em: <http://www12.senado.leg.br/noticias/entenda-oassunto/cpmf>. Acesso em: 2 nov. 2016.

BRASIL. Emenda Constitucional n. 10, de 4 de março de 1996. Altera os arts. 71 e 72 do Ato das Disposiçōes Constitucionais Transitórias, introduzidos pela Emenda Constitucional de Revisão n. 1, de 1994. Diário Oficial da União. Distrito Federal, 7 de março de 1996.

BRASIL. Emenda Constitucional n. 27, de 21 de março de 2000. Acrescenta o art. 76 ao ato das Disposições Constitucionais Transitórias, instituindo a desvinculação de arrecadação 
•• Tributação, direitos fundamentais e desenvolvimento

de impostos e contribuições sociais da União. Diário Oficial da União. Distrito Federal, 22 de março de 2000.

BRASIL. Emenda Constitucional n. 93, de 21 de março de 2016. Altera o Ato das Disposições Constitucionais Transitórias para prorrogar a desvinculação de receitas da União e estabelecer a desvinculação de receitas dos Estados, Distrito Federal e Municípios. Diário Oficial da União. Distrito Federal, 9 de setembro de 2016.

BRASIL. Emenda Constitucional n. 93, de 21 de março de 2016. Altera o Ato das Disposiçõoes Constitucionais Transitórias para prorrogar a desvinculação de receitas da União e estabelecer a desvinculação de receitas dos Estados, Distrito Federal e Municípios. Diário Oficial da União. Distrito Federal, 9 de setembro de 2016.

BRASIL. Informativo STF, Brasília, 15 a 19 de dezembro de 2003, n. 334. Disponível em: <http://www.stf.jus.br//arquivo/informativo/documento/informativo334.htm>. Acesso em: 23 out. 2016.

BRASIL. Informativo STF, Brasília, 14 a 18 de abril de 2008, n. 502. Disponível em: <http://www.stf.jus.br/arquivo/informativo/documento/informativo502.htm>. Acesso em: 23 out. 2016.

BRASIL. Lei n. 5.172, de 25 de outubro de 1966. Dispõe sobre o Sistema Tributário Nacional e institui normas gerais de direito tributário aplicáveis à União, Estados e Municípios. Diário Oficial da União, Distrito Federal, 27 de outubro de 1966.

BRASIL. Nova Emenda Constitucional prorroga Desvinculação de Receitas da União. Disponível em: <http://www12.senado.leg.br/noticias/audios/2016/09/nova-emendaconstitucional-prorroga-desvinculacao-de-receitas-da-uniao>. Acesso em: 18 out. 2016.

BRASIL. O que é e para que serve a desvinculação de receitas da Uniāo (DRU)? Disponível em: <http://www.brasil-economia-governo.org.br/2011/12/05/o-que-e-e-para-que-servea-desvinculacao-de-receitas-da-uniao-dru/>. Acesso em: 18 out. 2016.

BRASIL. Prorrogação da DRU é fundamental para politicas sociais e de investimento, afirma ministra. Disponível em: <http://www.planejamento.gov.br/assuntos/orcamento/ noticias/prorrogacao-da-dru-e-fundamental-para-politicas>. Acesso em 23 out. 2016.

BRASIL. Recessão antecipa a crise na Previdência. Disponível em: <http://economia. estadao.com.br/noticias/geral,recessao-antecipa-a-crise-na--previdencia,1769666> Acesso em: 25 out. 2016.

BRASIL. Supremo Tribunal Federal. RE 635682/RJ. Relator: Min. Gilmar Mendes. Data de Julgamento: 25.04.2013. Data de Publicação: 24/05/2013. Disponível em: <http://stf.jusbrasil.com.br/jurisprudencia/23308019/recurso-extraordinario-re-635682rj-stf/inteiro-teor-111675582>. Acesso em: 29 out. 2016.

BRASIL. Supremo Tribunal Federal. ADI $4048 \mathrm{MC} / \mathrm{DF}$. Relator: Min. Gilmar Mendes, Data de julgamento: 17.04.2008. Data de Publicação: 30.04.2008. Disponível em: <http://www.stf. jus.br/arquivo/informativo/documento/informativo502.htm>. Acesso em: 23 out. 2016 . 
BRASIL. Supremo Tribunal Federal. RE 227.832/PR. Relator: Min. Ricardo Lewandowski. Data de Julgamento: 12.08.2010. Data de Publicação: 24.09.2010. Disponível em: <http://redir.stf.jus.br/paginadorpub/paginador.jsp?docTP=AC\&docID =614536>. Acesso em: 29 out. 2016.

BRASIL. Supremo Tribunal Federal. ADI 2.556 e ADI 2.568. Relator: Min. Joaquim Barbosa. Data de Julgamento: 13.06.2012. Data de Publicação: 20.09.2012. Disponível em: <http://www.stf.jus.br/portal/constituicao/artigoBd.asp? item=1634>. Acesso em: 26 nov. 2016.

BRASIL. Supremo Tribunal Federal. ADI $4048 \mathrm{MC} / \mathrm{DF}$. Relator: Min. Gilmar Mendes, Data de julgamento: 17.04.2008. Data de Publicação: 30.04.2008. Disponível em: <http://www.stf. jus.br/arquivo/informativo/documento/informativo502.htm>. Acesso em: 23 out. 2016.

BRASIL. Supremo Tribunal Federal. ADI 4049. Relator: Min. Teori Zavascki. Data de Julgamento: 10.03.2016. Data da Publicação: 16.03.2016. Disponível em: <http://stf. jusbrasil.com.br/jurisprudencia/321786934/acao-direta-de-inconstitucionalidade-adi4049-df-distrito-federal-0001092-0320080010000>. Acesso em: 16 out. 2016.

BRASIL. Supremo Tribunal Federal. ADI 2925. Relator: Rel. Orig. Min. Ellen Gracie, Rel. p/ o Acórdão Min. Marco Aurélio. Data de Julgamento: 19.12.2003. Data de Publicação: 13.02.2004. Disponível em: <http://www.stf.jus.br//arquivo/informativo/ documento/informativo334.htm>. Acesso em: 23 out. 2016.

BRASIL. Supremo Tribunal Federal. RE 183.906. Relator: Min. Marco Aurélio. Data de Julgamento: 18.09.1997. Data de Publicação: 29.09.1997. Disponível em: <http://redir. stf.jus.br/paginadorpub/paginador.jsp?docTP=AC \&docID=227617>. Acesso em: 16 out. 2016.

BRASIL. Supremo Tribunal Federal. RE 793564/PE. Relator: Min. Marco Aurélio. Data de Julgamento: 12.08.2014. Data de Publicação: 01.10.2014. Disponível em: <http://stf. jusbrasil.com.br/jurisprudencia/25286560/agreg-no-recurso-extraordinario-re-793564pe-stf>. Acesso em: 23 out. 2016.

BRASIL. Supremo Tribunal Federal. ADI 830/DF. Relator: Min. Moreira Alves. Data de Julgamento: 14.04.1993. Data de Publicação: 16.09.1994. Disponível em: <http://redir. stf.jus.br/paginadorpub/paginador.jsp?doc $\mathrm{TP}=\mathrm{AC} \&$ docID $=266554>$. Acesso em: 26 out. 2016.

BRASIL. Supremo Tribunal Federal. RE 805477/ES. Relator: Min. Roberto Barroso. Data de Julgamento: 07.10.2014. Data de Publicação: 30.10.2014. Disponível em: <http://stf.jusbrasil.com.br/jurisprudencia/25300805/agreg-no-recurso-extraordinariore-805477-es-stf>. Acesso em: 23 out. 2016.

BRASIL. Supremo Tribunal Federal. RE 805477/ES. Relator: Min. Roberto Barroso. Data de Julgamento: 07.10.2014. Data de Publicação: 30.10.2014. Disponível em: <http:// redir.stf.jus. br/paginadorpub/paginador.jsp?docTP=TP\&docID =7085838>. Acesso em: 23 out. 2016. 
•• Tributação, direitos fundamentais e desenvolvimento

BRASIL. Supremo Tribunal Federal. RE 566007/RS. Relator: Min. Cármen Lúcia. Data de Julgamento: 02/04/2014. Data de Publicação: 24.04.2014. Disponível em: <http:// redir.stf.jus.br/paginadorpub /paginador.jsp?docTP=TP\&docID=7719221 >. Acesso em: 23 out. 2016.

BREYNER, Frederico Menezes. Inconstitucionalidade da desvinculação das receitas da união (DRU) quanto às contribuições sociais sob a ótica dos direitos prestacionais fundamentais. Revista do Centro Acadêmico Afonso Pena, v. 9, n. 1, 2006.

BULOS, Uadi Lammêgo. Curso de direito constitucional. 9. ed. São Paulo: Saraiva, 2015. CARVALHO, Paulo de Barros. Curso de direito tributário. 18. ed. São Paulo: Saraiva, 2007.

CASTELLANI, Fernando F. Contribuições especiais e sua destinação. São Paulo: Noeses, 2009.

CUNHA, Carlos Renato. Análise do arquétipo da regra-matriz de incidência tributária da contribuição para o custeio da iluminação pública. Revista de Direito Público da Procuradoria-Geral do Municipio de Londrina, v. 1, n. 1, p. 33-56, 2012.

DE MOURA, Carolina Maria Melo; GON, Diego Souza. Desvio de finalidade da contribuição de intervenção no domínio econômico incidente sobre combustíveis. Revista do Direito Público, v. 2, n. 1, p. 63-74, 2007.

DERZI, Misabel Abreu Machado; SANTIAGO, Igor Mauler. Revista Internacional de Direito Tributário, Belo Horizonte, v. 1, n. 2, jul./dez. 2004.

DIAS, Fernando Álvares Correia. Desvinculação de receitas da União, gastos sociais e ajuste fiscal. 2008. Consultoria Legislativa do Senado Federal. Brasília, 2008. Disponível em: $\quad$ http://www2.senado.leg.br/bdsf/bitstream/handle/id/94273/Texto\%20p\%20 discuss \%C3\%A3o\%2039.pdf? sequence=4>. Acesso em: 30 nov. 2016.

DIAS, Fernando Álvares Correia; TAVARES, José Fernando Cosentino. Impacto da desvinculação de receitas da União no orçamento federal e em gastos sociais. Cadernos Aslegis, v. 3, n. 9, p. 50-77, 1999.

DOMINGUES, Gabriel Demetrio. Uma contribuição à teoria das contribuiçôes. 2013. 96f. Dissertação (Mestrado em Direito) - Faculdade de Direito, Universidade do Estado do Rio de Janeiro, Rio de Janeiro, 2013.

ENCARNAÇÃO. Iasmine Souza. O STF e o orçamento: controle de constitucionalidade das leis orçamentárias. Disponível em: <http://www.ambito-juridico.com.br/site/?n_ link=revista_artigos_leitura\&artigo_id=14376>. Acesso em: 4 nov. 2016.

GIAMBIAGI, Fábio; ALÉM, Ana Cláudia. Finanças públicas: teoria e prática no Brasil. 4. ed. rev e atual. Rio de Janeiro: Elsevier, 2011.

GOMES, Flávia Helena. Das implicações tributárias do desvio de finalidade na destinação do produto arrecadado com a CIDE-combustíveis. Revista do Direito Público, v. 3, n. 3, p. 144-162, 2008. 
MACHADO, Hugo Brito de. Curso de direito tributário. 24. ed. São Paulo: Malheiros, 2005.

MARQUES, Rosa Maria M.; MENDES, Áquilas. Os dilemas do financiamento do SUS no interior da seguridade social. Economia e Sociedade, v. 14, n. 1, p. 159-175, 2016.

MELLO, Elizabete Rosa de. Direito fundamental a uma tributação justa. São Paulo: Atlas, 2013.

MENDES, Gilmar Ferreira; BRANCO, Paulo Gustavo. Curso de direito constitucional. 10. ed. São Paulo: Saraiva, 2015.

OLIVEIRA, Régis Fernandes de. Curso de direito financeiro. 5. ed. São Paulo: RT, 2013.

PAULSEN, Leandro. Curso de direito tributário. 4. ed. Porto Alegre: Livraria do Advogado, 2012.

PAULSEN, Leandro; MELO, José Eduardo Soares de. Impostos Federais, Estaduais e Municipais. 7. ed. rev e atual. Porto Alegre: Livraria do Advogado, 2012.

PAULSEN, Leandro; VELLOSO, Andrei Pitten. Contribuiçôes: teoria geral. Contribuições em espécie. 2. ed. Porto Alegre: Livraria do Advogado, 2013.

RODRIGUES, Sirley Aparecida Lopes et al. Contribuição previdenciária à luz da regra matriz de incidência tributária. 2014. 120f. Dissertação (Mestrado em Direito) - Faculdade de Direito, Pontifícia Universidade Católica de São Paulo, São Paulo, 2014.

SCAFF, Fernando Facury. Direitos humanos e a desvinculação das receitas da União. Revista de Direito Administrativo, v. 236, p. 33-50, 2004.

SCHOUERI, Luís Eduardo. Direito tributário. 3. ed. São Paulo: Saraiva, 2013.

SILVA, José Afonso da. Comentário contextual à Constituição. 8. ed. São Paulo: Malheiros, 2011. 
